\title{
Can bryophyte groups increase functional resolution in tundra ecosystems ${ }^{1}$
}

\author{
Signe Lett, Ingibjörg S. Jónsdóttir, Antoine Becker-Scarpitta, Casper T. Christiansen, \\ Heinjo During, Flemming Ekelund, Gregory H.R. Henry, Simone I. Lang, Anders \\ Michelsen, Kathrin Rousk, Juha M. Alatalo, Katlyn R. Betway, Sara B. Rui, Terry \\ Callaghan, Michele Carbognani, Elisabeth J. Cooper, J. Hans C. Cornelissen, Ellen \\ Dorrepaal, Dagmar Egelkraut, Tatiana G. Elumeeva, Siri V. Haugum, Robert D. \\ Hollister, Annika K. Jägerbrand, Frida Keuper, Kari Klanderud, Esther Lévesque, Xin \\ Liu, Jeremy May, Pascale Michel, Martin Mörsdorf, Alessandro Petraglia, Christian \\ Rixen, Bjorn J.M. Robroek, Agnieszka M. Rzepczynska, Nadejda A. Soudzilovskaia, \\ Anne Tolvanen, Vigdis Vandvik, Igor Volkov, Irina Volkova, and Kristel van Zuijlen
}

\begin{abstract}
The relative contribution of bryophytes to plant diversity, primary productivity, and ecosystem functioning increases towards colder climates. Bryophytes respond to environmental changes at the species level, but because bryophyte species are relatively difficult to identify, they are often lumped into one functional group. Consequently, bryophyte function remains poorly resolved. Here, we explore how higher resolution of bryophyte functional diversity can be encouraged and implemented in tundra ecological studies. We briefly review previous bryophyte functional classifications and the roles of bryophytes
\end{abstract}

Received 13 November 2020. Accepted 30 June 2021.

S. Lett,* F. Ekelund, K. Rousk, and A.M. Rzepczynska. Terrestrial Ecology Section, Department of Biology, University of Copenhagen, Universitetsparken 15, 2100 Copenhagen, Denmark.

I.S. Jónsdóttir.* Institute of Life and Environmental Sciences, University of Iceland, Sturlugata 7, 102 Reykjavik, Iceland. A. Becker-Scarpitta. Spatial Food Web Ecology Group \& Research Centre for Ecological Change, Faculty of Agriculture and Forestry, University of Helsinki, PO Box 27 (Viikinkaari), 00014, Helsinki, Finland.

A. Michelsen, C.T. Christiansen. Terrestrial Ecology Section, Department of Biology, University of Copenhagen, Universitetsparken 15, 2100 Copenhagen, Denmark; Center for Permafrost (CENPERM), University of Copenhagen, Øster Voldgade 10, 1350 Copenhagen K, Denmark.

H. During. Ecology \& Biodiversity, Department of Biology, Utrecht University, $3584 \mathrm{CH}$ Utrecht, The Netherlands.

G.H.R. Henry.* Department of Geography, University of British Columbia, Vancouver, BC V6T 1Z2, Canada.

S.I. Lang. Department of Arctic Biology, The University Centre in Svalbard (UNIS), 9171 Longyearbyen, Svalbard, Norway. J.M. Alatalo. Environmental Science Center, Qatar University, Doha, Qatar.

K.R. Betway and R.D. Hollister.* Biology Department, Grand Valley State University, 1 Campus Dr., Allendale, MI 49401 USA.

S.B. Rui, D. Egelkraut, S.V. Haugum, P. Michel, and V. Vandvik. Department of Biological Sciences, University of Bergen, PO Box 7801, N-5020 Bergen, Norway.

T. Callaghan. Department of Animal and Plant Sciences, University of Sheffield UK, UK; Department of Botany, Tomsk State University, Russia.

M. Carbognani and A. Petraglia.* Department of Chemistry, Life Sciences and Environmental Sustainability, University of Parma, Parco Area delle Scienze 11/A, I-43124, Parma, Italy.

Corresponding author: Signe Lett (e-mail: signe.lett@bio.ku.dk).

${ }^{1}$ This paper is part of a Special Issue entitled: Impacts of climate change on tundra ecosystems: Three decades of results from the International Tundra Experiment (ITEX).

*Signe Lett, Robert D. Hollister, Kari Klanderud, Jeremy May, Alessandro Petraglia, Christian Rixen served as Guest Editors, Ingibjörg S. Jónsdóttir served as a Guest Editor/Associate Editor, and Gregory H.R. Henry served as a Guest Editor/ Consulting Editor at the time of manuscript review and acceptance; peer review and editorial decisions regarding this manuscript were handled by Anne Bjorkman and Melissa Lafrenière.

Copyright remains with the author(s) or their institution(s). This work is licensed under a Creative Commons Attribution 4.0 International License (CC BY 4.0) http://creativecommons.org/licenses/by/4.0/deed.en_GB, which permits unrestricted use, distribution, and reproduction in any medium, provided the original author(s) and source are credited. 
in tundra ecosystems and their susceptibility to environmental change. Based on shoot morphology and colony organization, we then propose twelve easily distinguishable bryophyte functional groups. To illustrate how bryophyte functional groups can help elucidate variation in bryophyte effects and responses, we compiled existing data on water holding capacity, a key bryophyte trait. Although plant functional groups can mask potentially high interspecific and intraspecific variability, we found better separation of bryophyte functional group means compared with previous grouping systems regarding water holding capacity. This suggests that our bryophyte functional groups truly represent variation in the functional roles of bryophytes in tundra ecosystems. Lastly, we provide recommendations to improve the monitoring of bryophyte community changes in tundra study sites.

Key words: mosses, Arctic-Alpine, environmental change, functional traits, water holding capacity.

Résumé : La contribution relative des bryophytes à la diversité végétale, à la productivité primaire et au fonctionnement des écosystèmes s'accroît vers les climats plus froids. Les bryophytes répondent aux changements environnementaux au niveau de l'espèce, mais puisque les espèces de bryophytes sont relativement difficiles à identifier, elles sont souvent regroupées en un seul groupe fonctionnel. Par conséquent, la fonction des bryophytes reste mal résolue. Les auteurs explorent ici comment une meilleure résolution de la diversité fonctionnelle des bryophytes peut être encouragée et mise en œuvre dans les études écologiques de la toundra. Ils passent brièvement en revue les classifications fonctionnelles précédentes des bryophytes et les rôles des bryophytes dans les écosystèmes de la toundra et leur sensibilité aux changements environnementaux. Sur la base de la morphologie des pousses et de l'organisation des colonies, ils proposent ensuite douze groupes fonctionnels de bryophytes faciles à distinguer. Pour illustrer comment les groupes fonctionnels de bryophytes peuvent aider à élucider la variation des effets et des réponses des bryophytes, ils ont compilé les données existantes sur la capacité de rétention d'eau, une caractéristique clé des bryophytes. Bien que les groupes fonctionnels de végétaux puissent masquer une variabilité interspécifique et intraspécifique potentiellement élevée, ils ont constaté une meilleure séparation des moyennes des groupes fonctionnels de bryophytes par rapport aux systèmes de regroupement précédents concernant la capacité de rétention d'eau. Cela suggère que les groupes fonctionnels de bryophytes proposés par les auteurs représentent réellement la variation des rôles fonctionnels des bryophytes dans les écosystèmes de la toundra. Enfin, ils formulent des recommandations pour améliorer la surveillance des changements de la communauté bryophyte dans les sites d'étude de la toundra. [Traduit par la Rédaction]

E.J. Cooper. Department of Arctic and Marine Biology, Biosciences Fisheries and Economics, UiT-The Arctic University of Norway, N-9037 Tromsø, Norway.

J.H.C. Cornelissen. Department of Ecological Sciences, Vrije Universiteit, 1081 HV Amsterdam, The Netherlands.

E. Dorrepaal. Climate Impacts Research Centre, Department of Ecology and Environmental Science, Umeå University, Sweden.

T.G. Elumeeva. Department of Ecology and Plant Geography, Biological Faculty, Lomonosov Moscow State University, Leninskie Gory, 1/12, 119234 Moscow, Russia.

A.K. Jägerbrand. Ecology and Environmental Science, RLAS, Halmstad University, Halmstad, Sweden.

F. Keuper. BioEcoAgro Joint Research Unit, INRAE, F-02000 Barenton-Bugny, France.

K. Klanderud* and K. Zuijlen. Faculty of Environmental Sciences and Natural Resource Management, Norwegian University of Life Sciences, P.O. Box 5003, 1432, Ås, Norway.

E. Lévesque. Département des Sciences de l'environnement et Centre d'études nordiques, Université du Québec à TroisRivières, Trois-Rivières, QC G8Z 4M3, Canada.

X. Liu. Chinese Academy of Sciences Key Laboratory of Mountain Ecological Restoration and Bioresource Utilization \& Ecological Restoration and Biodiversity Conservation Key Laboratory of Sichuan Province, Chengdu Institute of Biology, Chinese Academy of Sciences, Chengdu 610041, China.

J. May.* Department of Biology, Florida International University, 11200 SW 8th Street, Miami, FL 33199-2156, USA.

M. Mörsdorf. Department of Geobotany, University of Freiburg, Schänzlestrasse 1, 79104 Freiburg, Germany.

C. Rixen.* WSL Institute for Snow and Avalanche Research SLF, Flüelastr. 11, 7260 Davos Dorf, Switzerland.

B.J.M. Robroek. Aquatic Ecology \& Environmental Biology, Institute for Water and Wetland Research, Faculty of Science, Radboud University Nijmegen, AJ 6525 Nijmegen, The Netherlands.

N.A. Soudzilovskaia. Centre for environmental Sciences, Hasselt University, Martelarenlaan 42, 3500 Hasselt, Belgium. A. Tolvanen. Natural Resources Institute Finland, B.O. Box 413, 90014 Oulu, Finland.

I. Volkov. Laboratory of Biodiversity and Ecology, Tomsk State University, Lenin pr., 36, 634050 Tomsk, Russia.

I. Volkova. Department of Botany and Laboratory of Ecosystem and Climate Change Studies, Tomsk State University, Lenin pr., 36, 634050 Tomsk, Russia. 
Mots-clés : mousses, Arctique-Alpin, changement environnemental, traits fonctionnels, capacité de rétention d'eau.

\section{Introduction}

In the Arctic, bryophytes represent 30\% of all plant species (Walker and Raynolds 2011). Unlike the general trend for vascular plants, regional bryophyte species richness does not decline when moving from the equator towards the poles (Geffert et al. 2013; Mateo et al. 2016). In many tundra ecosystem types, bryophytes contribute significantly ( $>50 \%)$ to primary production and standing biomass (Wielgolaski 1971; Huemmrich et al. 2010) and play important roles for soil moisture, biogeochemical cycling, surface energy balance, and species diversity (e.g., Lindo and Gonzalez 2010; Turetsky et al. 2012). Tundra ecosystems are facing dramatic shifts in structure and function due to environmental change, which affects the abundance of bryophytes (Elmendorf et al. 2012a, 2012b; Lang et al. 2012; Olofsson et al. 2014; Cooper et al. 2019). However, although both functionality of bryophytes and their responses to environmental change differ considerably among species (Cornelissen et al. 2007; Hudson and Henry 2010; Lang et al. 2012) very few field studies include bryophytes at the species or other subgroup level. Therefore, studies are largely inconclusive and speculative in predicting responses of tundra bryophyte communities to environmental changes (Elmendorf et al. 2012a, 2012b) and the potential consequences of these changes for ecosystem functioning.

The resolution of the bryophyte component in tundra vegetation and ecosystem studies could be increased considerably by applying relevant bryophyte functional groups. Traditionally, functional classification has been used in the opposite manner as an effort to reduce complexity in, for example, vascular plant ecology using "plant functional types". Such a priori functional grouping has been challenged because effect and response traits do not necessarily match. Therefore, a good starting point for establishing fine-resolution linkages between bryophyte abundance, environmental changes, and ecosystem functioning could be to assign bryophyte species to functional groups through post hoc trait-based aggregation. This is done increasingly for other primary producer groups (Thomas et al. 2019; Mauffrey et al. 2020), because it directly provides ecologically meaningful functional groups. Such groups translate and aggregate species responses to more general functional responses and allow cross-site comparisons of responses regardless of species (Lavorel et al. 1997). However, for bryophytes the challenge is not limited to translating species into function.

Bryophyte species identification, as such, is challenging, especially in the field. It is time-consuming and requires identification skills that few ecologists possess (Grace 1995). In practice, this causes most field ecologists to lump bryophytes into one group (e.g., bryophytes or even as "non-vascular plants", with lichens as "cryptogams"), or two or more bryophyte groups (e.g., "Sphagnum" and "other bryophyte species"). Consequently, important ecological information is lost, comparison between different studies is not straightforward and opportunities for addressing functional responses of bryophytes across sites and at larger scales are hampered. Therefore, for bryophytes, using a priori defined functional groups, based on coarse morphological characteristics that can be identified in the field, may be a more promising approach. Previous work on bryophyte classifications that has been based on life history traits (During 1979), position of sexual reproductive organs (La Farge-England 1996), and bryophyte colony structure (Mägdefrau 1982) offer useful insights about bryophyte ecology, but none of them focus primarily on functional diversity. 
Here we propose a priori defined, field-identifiable "bryophyte functional groups" (BFGs) as a cost- and time-efficient, and meaningful way to increase bryophyte data resolution, allow measurement of change in bryophyte communities in response to environmental change, obtain comparable bryophyte data across tundra habitats and sites, and enhance understanding of bryophyte ecosystem effects and responses. To this end, we (1) provide an overview of the role of bryophytes in tundra ecosystems and their susceptibility to environmental change; (2) review previous efforts to group bryophytes; and (3) build on these efforts to propose twelve field identifiable BFGs. (4) We evaluate the relevance of these BFGs in relation to water holding capacity (WHC), a functionally important and commonly measured bryophyte trait, in a case study where we re-analyze existing data. As such, if BFGs separate into more than one cluster based on water holding capacity, the groups improve the functional resolution compared with the commonly used single "bryophytes" group for ecosystem function governed by this trait. Finally, we discuss how BFGs may differ in regard to other key bryophyte functions and provide recommendations on how to apply BFGs in tundra ecological studies.

\section{Bryophytes in tundra ecosystems}

Ecosystem functions and functional diversity of tundra bryophytes

An important feature of tundra bryophytes is that they often grow in dense carpets or colonies in many habitats. It is in the colony form that bryophytes most strongly affect the environment through their physical presence, as well as biogeochemically and biotically through interactions with other organisms in the ecosystem (Fig. 1). The physical properties of a dense and deep bryophyte layer may significantly control the soil environment by buffering substrate moisture and insulate soil from diurnal and annual air temperature variation with consequences for biogeochemical processes (Gornall et al. 2007; Soudzilovskaia et al. 2013; Jaroszynska 2019), active layer development and permafrost ice content (Jorgenson et al. 2010). Through their effects on water balance bryophytes affect energy partitioning and decrease ecosystem ground heat flux (Blok et al. 2011) and affect surface albedo (May et al. 2018). Biogeochemically, bryophytes are important as they contribute to the ecosystem carbon $(C)$ balance through their great abundance, high $C$ use efficiency and because they are active beyond the short vascular plant growing season (Douma et al. 2007; Woodin et al. 2009; Street et al. 2012, 2013). Bryophytes control the input of nitrogen $(\mathrm{N})$ to the ecosystem through associations with $\mathrm{N}_{2}$ fixing bacteria and by efficiently immobilizing $\mathrm{N}$ from deposition within the bryophyte layer (Jónsdóttir et al. 1995). Both $\mathrm{C}$ and $\mathrm{N}$ fixation rates are highly dependent on moisture conditions within the bryophyte tissue (Solheim and Zielke 2003; Turetsky 2003; Gavazov et al. 2010; Lett and Michelsen 2014; Rousk et al. 2015, 2017). Last, their recalcitrant litter and effects on $\mathrm{pH}$ are an important feature, which slows the release of C and N cycling in the ecosystem (Russell 1990; Lang et al. 2009; Soudzilovskaia et al. 2010).

Through a combination of these physical and biochemical effects, bryophytes interact with the biotic environment. As such, they affect vascular plant growth and establishment through competition and facilitation (Gornall et al. 2011; Soudzilovskaia et al. 2011; Keuper et al. 2011; Lett et al. 2017, 2018, 2020). For instance, bryophytes can grow in places where vascular plants cannot root, such as rocks and glacial forelands, where they over time form an organic substrate which can later be colonized by plants (Jones and Henry 2003; Gavini et al. 2019). Their colonies comprise a matrix for unique food webs of microfauna and microbes (Lindo and Gonzalez 2010; Glime 2012; Jonsson et al. 2015). Although their dietary value is low (Prop and Vulink 1992; Hübner 2007), bryophytes are also consumed by vertebrate herbivores such as rodents, geese, reindeer/caribou, and muskox, (Glime 2006; Ihl and Barboza 2007; Bjørkvoll et al. 2009; Soininen et al. 2013). 
Fig. 1. Schematic overview of some of the structural and functional roles of the bryophyte layer (bryosphere) in tundra ecosystems. The bryosphere (green) does not substantially penetrate the soil but creates a zone between the active layer (brown) belowground and the atmosphere (light blue) aboveground. Teal-framed boxes are physical properties (solid) and conditions (dashed), yellow-framed boxes are biogeochemical pools (solid) and processes (dashed) and pink-framed boxes are the biota. Dashed arrow indicates an uncertain connection between boxes. The diagram does not include all environmental factors acting on bryophyte functioning.

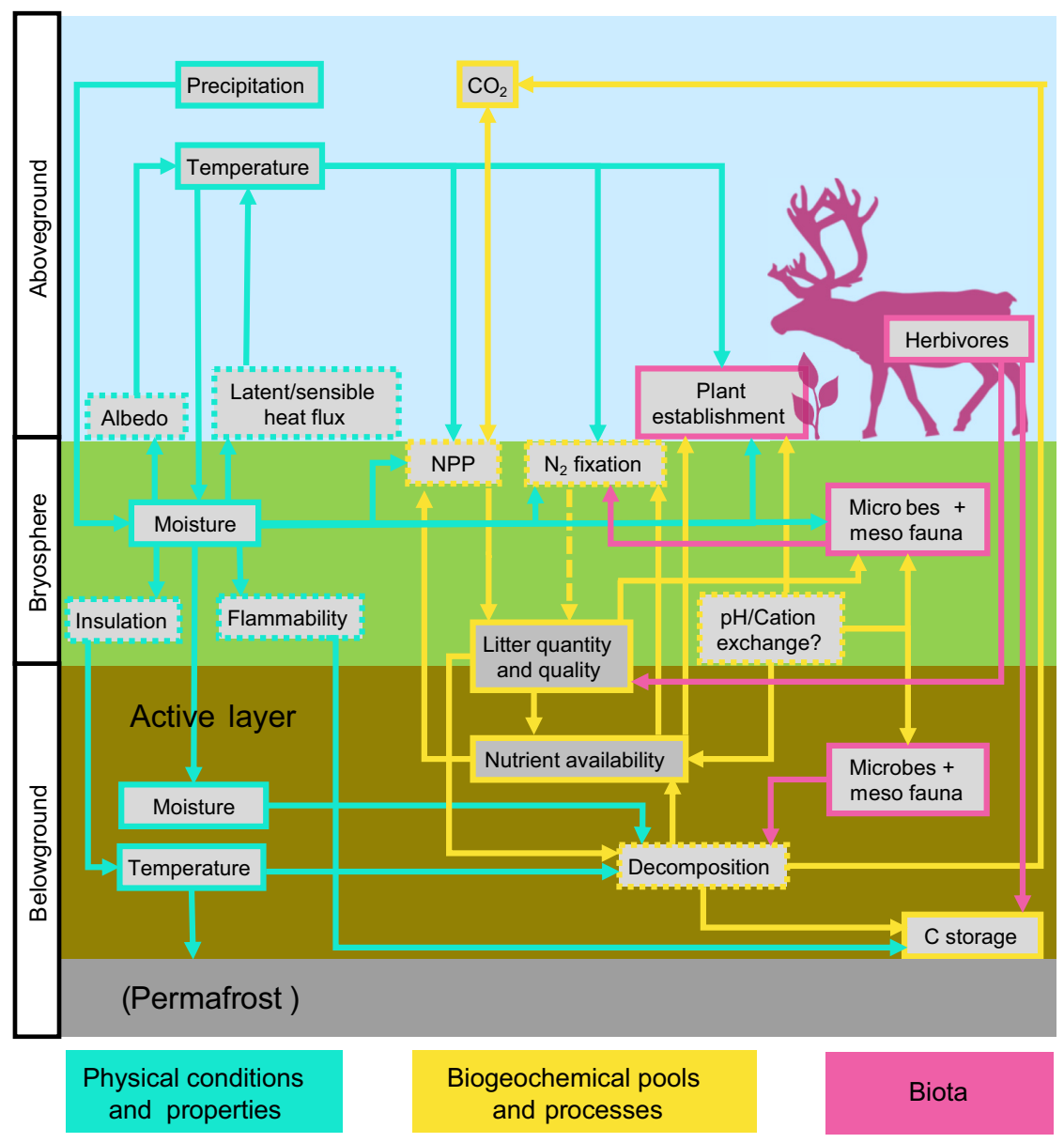

Bryophyte ecosystem functional trait data are still scarce in comparison to such data for vascular plants (St. Martin and Mallik 2017). Morphological shoot traits, and colony traits such as moss layer depth, colony density, and surface texture and color, are important for determining the physical effects of bryophytes on tundra ecosystems. For instance, decomposition rates can vary more than 10 -fold between the extremely recalcitrant Sphagnum mosses and more nitrogen rich species such as Ptilidium ciliare (L.) Hampe and Pleurozium schreberi (Brid.) Mitt. (Lang et al. 2009; van Zuijlen et al. 2020) and water holding capacity may vary five-fold (Elumeeva et al. 2011). Such information is obtained by systematically screening species for important effect traits.

\section{Responses in bryophyte cover to environmental change in tundra ecosystems}

As for any tundra plant, climate warming is likely to promote bryophyte growth if water and nutrients are not limiting (Douma et al. 2007). Wetter and warmer climates, which are 
now occurring and expected in much of the tundra biome (Bintanja and Andry 2017; Thomas et al. 2018), should, in principle, promote bryophyte growth and, thus, abundance. Data on bryophyte abundance responses to climate change are scarce compared with those on vascular plants, but available data from the North American and European Arctic show an overall decline in bryophyte abundance in response to climate warming across tundra ecosystems (Elmendorf et al. 2012a, 2012b). This decline seems more pronounced in moister sites and has been attributed to indirect effects of warming through competition from vascular plants (shading). However, bryophyte responses to warming vary substantially across species and sites, and habitats within sites. For example, no effect of experimental warming on bryophyte covers was observed in a subarctic Racomitrium lanuginosum (Hedw.) Brid. heath (Jónsdóttir et al. 2005), positive effects of warming were observed for common boreal bryophyte species in Arctic and subarctic alpine tundra plant communities (Lang et al. 2012) and for bryophytes in various habitats within a High Arctic tundra site (Hudson and Henry 2010; Edwards and Henry 2016).

Changes in water availability under warming, or susceptibility to other global change drivers may also contribute to the observed general negative trends. Unlike vascular plants, most bryophytes are poikilohydric and cannot actively control their water balance. They have no or only thin leaf cuticles and do not have leaf stomates. Most species do not have efficient vascular systems (but see Brodribb et al. 2020) nor true roots, and access water and nutrients passively through their leaves. Bryophytes can, to varying degrees, tolerate desiccation during dry periods after which they return to normal physiological activity (Proctor and Tuba 2002; Proctor et al. 2007). Increased herbivore pressure may disturb the bryophyte layer in the tundra, as, for example, through spring grubbing by the increasing goose populations in the Arctic (Kotanen and Jefferies 1997; Wal et al. 2007). Exclusion of lemmings and reindeer (Olofsson et al. 2014) and sheep (Jónsdóttir 1991) in subarctic alpine heath tundra increases bryophyte cover and colony depth through promotion of tall stature bryophytes. Furthermore, goose and sheep grazing can increase small scale bryophyte diversity at the species level (Jónsdóttir 1984; Jasmin et al. 2008). Increased snow depth may promote bryophyte biomass production and cover (Dorrepaal et al. 2004; Paradis et al. 2016; Cooper et al. 2019). Importantly, bryophytes show species-specific responses to multiple environmental factors operating at different spatial scales, with variable consequences for both community composition and total bryophyte cover across alpine and Arctic tundra regions.

\section{Functional trait responses to the environment and intraspecific variation}

By combining data for total bryophyte cover and species composition with data for bryophyte functional traits we can understand how environmental changes affect ecosystem functionality (Díaz and Cabido 2001). Some functional traits of bryophytes may, however, themselves be responsive to environmental change causing considerable intraspecific trait variation in addition to interspecific trait variation that is caused by species turnover. For example, bryophyte tissue phosphorus (P) content and shoot water holding capacity and growth showed high variation within species, whereas traits like $\mathrm{pH}, \mathrm{N}$ content, and litter decomposability showed less intraspecific than interspecific variation in alpine ecosystems (Jägerbrand et al. 2014; Roos et al. 2019; Zuijlen et al. 2020). However, Roos et al. (2019) concluded that bryophyte species turnover rather than intraspecific variation drove changes in community abundance-weighted means of all six measured traits ( $\mathrm{N}$ and $\mathrm{P}$ concentration and ratio, $\mathrm{pH}$, specific leaf area, and water holding capacity) across an elevational gradient. This supports the possibility to assign bryophyte species to groups, which could represent certain ecosystem functions. 


\section{Grouping of bryophytes}

Previous grouping of bryophytes

During $(1979,1992)$ identified life history types to classify bryophytes according to life strategies (e.g., life span and reproductive strategy, age and effort). Life history types may depend on the environment and life history traits are likely a key to understanding bryophyte population dynamics (Austrheim et al. 2005); however, they do not provide full insights into bryophyte functional roles in the ecosystem. Currently, the majority of trait data for bryophytes occurring in the TRY database are on life history traits (Kattge et al. 2020).

The growth form classification has often been used in combination with life form and (or) perichaetial position in the literature. La Farge-England (1996) distinguished growth form, life form, and perichaetial position and indicated which are environmentally modified versus genetically fixed. This provided a comprehensive and unambiguous way to assess the structure of moss (Bryophyta) individuals. They refer to growth form as the structure of individual shoots, including direction of growth and branch form. Here, growth form (modified by the environment) is differentiated from the perichaetial position (La Farge-England 1996). Perichaetial position, which classifies acrocarpy, cladocarpy, and pleurocarpy, is analyzed and reviewed with an evolutionary perspective within major Bryophyta lineages. Huttunen et al. (2018) mapped "carpy" phylogenetically across the lineages in an extensive review on bryophyte functional traits. They showed that perichaetial position alone does not determine the ecosystem function of bryophytes or how populations respond to environmental change. Growth form, by contrast, seems to influence how shoots are organized in colonies, which is thought to be important for ecosystem functioning (Bates 1998).

The life form classification of bryophytes was developed by Gimingham and Robertson (1950) and later refined and modified by Gimingham and Birse (1957); Mägdefrau (1982); Longton (1988); Grace (1995); Bates (1998); Hill et al. (2007) and Vanderpoorten and Goffinet (2009). The classification is based on the organization of the colony (group of shoots), although exact groups differ between authors. The life form classification integrates shoot morphology, such as branching pattern, growth direction, and colony structure. Grace (1995) showed that life forms are easily identifiable in the field across different levels of bryophyte identification skill. Importantly, it is convenient and meaningful to view bryophytes in terms of colonies rather than individuals to understand their effects on ecosystems (Bates 1998; Huttunen et al. 2018). Some physical colony properties, such as density and thickness, are directly related to ecosystem function, for example, insulation capacity and water holding capacity (Gornall et al. 2007; Elumeeva et al. 2011; Soudzilovskaia et al. 2013), whereas it is unknown whether chemical properties such as $\mathrm{N}$ content are linked to colony structure. Through their colony features bryophytes also affect the biotic environment, e.g., by hosting specific microfauna and mesofauna communities and through competition with or facilitation of other plants. Colonies in tundra ecosystems may be a mixture of several species (see below), which is a limitation to the life form classification. In conclusion, with their identifiability and ecological relevance, life forms integrate many of the desired features for a priori defined bryophyte functional groups.

\section{Modified "life form" as BFGs}

Our primary aim is to improve the representation of functionally different bryophytes in studies of tundra ecosystems by (1) focusing on the specific context of their responses to environmental changes and their effects on key ecosystem functions, and to encourage this by (2) proposing field-identifiable bryophyte functional groups as an alternative to determination at either the highest level, "species", and often not feasible level or the lowest level, 
"bryophyte", of resolution, which is too coarse to be useful. Therefore, our BFGs are chosen to be as morphologically distinct as possible to aid field identification. The BFGs are organized as a key (Fig. 2). The first steps follow the British Field Flora for Mosses and Liverworts (Atherton et al. 2010) and rely on morphological differences in macro-characteristics of the shoots and thalli, including branching pattern, and later steps divide groups based on colony structure, i.e., life forms (Fig. 2). By combining the growth form and life form concepts, we optimize the possibility to have functionally and morphological distinct groups, which are also taxonomically distinct.

The first split divides bryophytes into those with thallus and those with leaves (Fig. 2a). The "Thalloid" group contains liverworts and hornworts (Marchantiophyta and Anthocerotophyta, Fig. A1). Leafy bryophytes are divided based on the characteristics and placement of the leaves (Fig. $2 b$ ). Leaves can be arranged either in 2-3 ranks, mostly rounded or 2-lobed, and always without nerves, "Leafy liverworts", or have leaves which are arranged in a spiral and often with a nerve and acute tip, mosses (Bryophyta). Mosses are further divided into those with a capitulum, i.e., "Sphagnum" and those without capitulum, i.e., non-Sphagnum (Fig. 2c). The group and genus Sphagnum is easily recognized in the field as no other bryophytes have a capitulum. Non-Sphagnum mosses are divided into those with branched shoots and those with shoots not or infrequently branching (Fig. $2 d$ ) roughly corresponding to pleurocarps and acrocarps; cladocarps fall into both groups.

Colonies with shoots not or infrequently branching are divided into those with thick, non-transparent leaves and those with thin, more transparent leaves (Fig. 2e). Non-transparent leaves are a feature of "Polytrichales" (Fig. A1) and are caused by lamellae on the surface of the leaves. These lamellae are usually visible with a hand lens but a common feature of this group is that stems and leaves tend to be sturdier than in individuals in the contrasting group. The contrasting group, mosses with thin, more transparent leaves, form a large group, which is divided into "Cushions" and "Unbranched turfs" (Fig. 2f). "Unbranched turfs" correspond to Bates' turfs (Bates 1998), except our group includes only acrocarps. All shoots grow vertically from the substrate and, depending on the length of the shoots, "Unbranched turfs" are divided into "Short unbranched turfs" $(<5 \mathrm{~cm})$ and "Tall unbranched turfs" $(>5 \mathrm{~cm}$, Fig. $2 g)$. The "Cushions" have dome-shaped colonies (as in "cushion plants" such as Silene acaulis (L.) Jacq.). "Cushions" are divided into "Small cushions" and "Large cushions". Small cushions have shoots emerging from a shared, central origin so that shoots grow centrifugally and are less than $5 \mathrm{~cm}$ deep, Fig. 2h), e.g., genera Grimmia and Andreaea. "Large cushions" are more than $5 \mathrm{~cm}$ deep and may or may not have shoots growing from a central point. Species of this group also appear in other BFGs, e.g., Racomitrium lanuginosum in branched turf (see below) or Leucobryum glaucum (Hedw.) Ångstr., Dicranum elongatum Schleich. ex Schwägr., and Anoectangium aestivum (Hedw.) Mitt., in tall unbranched turfs.

Colonies with branched shoots are divided into "Dendroid", "Weft", "Mat" and "Branched turf" (Fig. 2i). The dendroid classification is technically a growth form. Dendroids have shoots that extend from horizontal stem and have branches placed towards the tip of the shoot making them resemble miniature trees. This is a small group and the most common species in tundra ecosystems is Climacium dendroides (Hedw.) F. Weber \& D. Mohr, but also e.g., Thamnobryum alopecurum Nieuwl. and Isothecium alopecuroides (Lam. ex Dubois) Isov. are found in subarctic areas. Wefts also have strongly branched shoots, but branches are distributed throughout the entire stem giving rise to the colloquial name, feather moss. Colonies appear loose and chaotic with large heavily branched shoots growing both vertically and horizontally. The emblematic boreal species Pleurozium schreberi (Hedw.) Schimp. and Hylocomium splendens (Hedw.) Schimp. belong to this group. Shoots of the Mat group grow horizontal to the substrate. Tips of shoots can become erect, giving 
Fig. 2. Bryophyte functional groups (BFGs) building on shoot morphology and life forms (Mägdefrau 1982). The left diagram functions as a key, which splits bryophytes into 12 BFGs listed in the right panel with their abbreviations (Abb.), short descriptions and examples of species. The key starts at the grey bubble and dichotomies leading from each step are indicated with a number and same color arrow. The 12 BFGs are placed at the periphery. Red crossed circles mark "not Sphagnum" or "not Polytrichales". Groups originating from orange bubbles can be collated to form broader functional groups. Note, in nature bryophytes often occur as a mixture of

species, usually individuals occupy the same BFG, but if they do not, the most abundant BFG should be recorded.

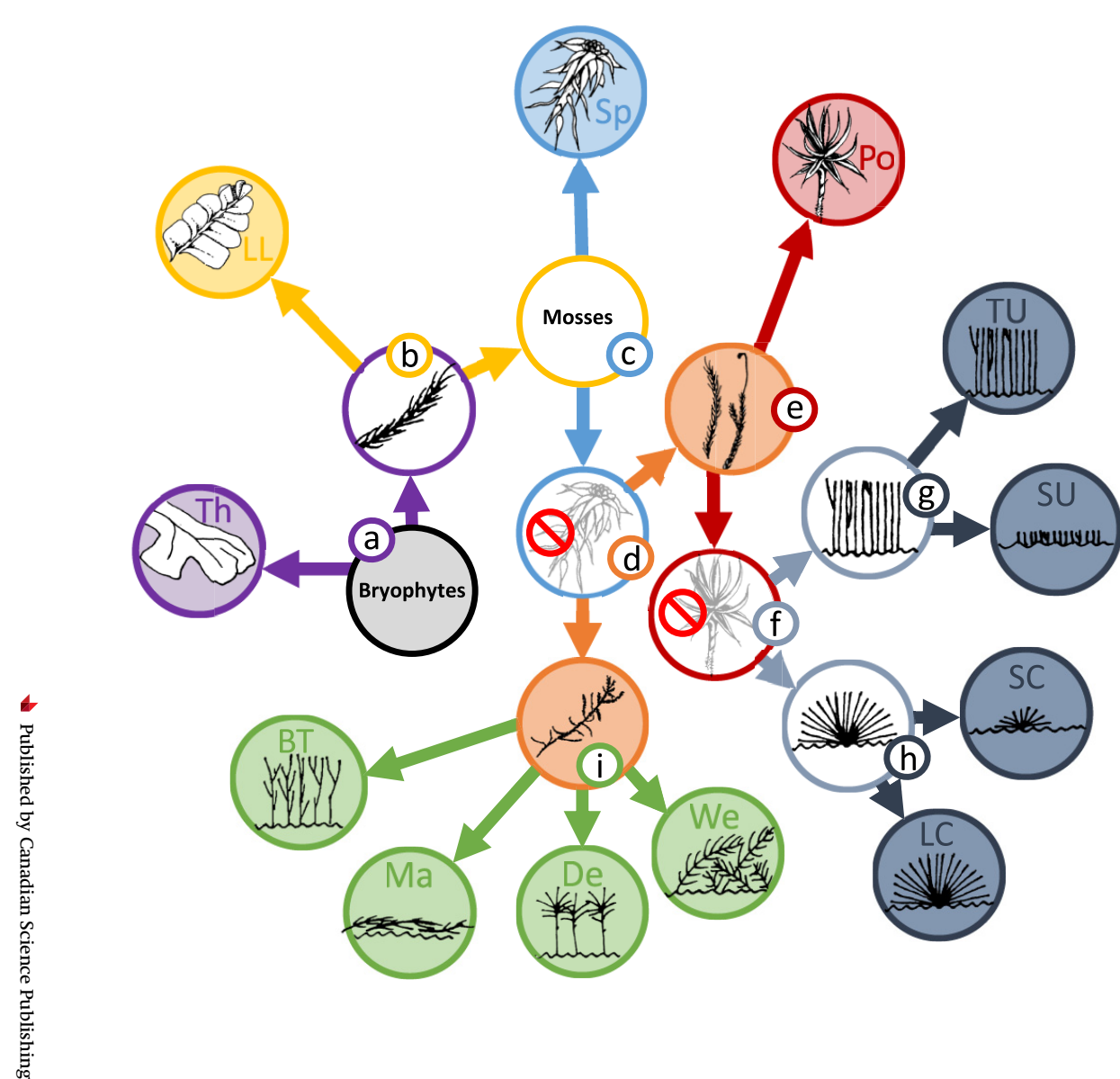

\begin{tabular}{|c|c|c|c|}
\hline Abb & BFG & Short description & $\begin{array}{l}\text { Examples of common/typical } \\
\text { species }\end{array}$ \\
\hline Th & $\begin{array}{l}\text { Thallose } \\
\text { liverwort and } \\
\text { hornwort }\end{array}$ & $\begin{array}{l}\text { Have undifferentiated vegetative } \\
\text { tissue (no stems and shoots). }\end{array}$ & $\begin{array}{l}\text { Marchantia foliacea, Aneura } \\
\text { pinguis }\end{array}$ \\
\hline LL & $\begin{array}{l}\text { Leafy } \\
\text { liverwort }\end{array}$ & $\begin{array}{l}\text { Shoots with leaves in 2-3 ranks, } \\
\text { mostly rounded or 2-lobed and } \\
\text { always without veins. }\end{array}$ & Ptilidium ciliare, Lophozia floerkii \\
\hline Sp & Sphagnum & $\begin{array}{l}\text { Have capitulum. All Sphagnum } \\
\text { species. }\end{array}$ & $\begin{array}{l}\text { Sphagnum fuscum, S. } \\
\text { girgensohnii, S. warnstorfii }\end{array}$ \\
\hline Po & Polytrichales & $\begin{array}{l}\text { Unbranched shoots. Lanceolate } \\
\text { leaves appear thick due to lamellae } \\
\text { parallel to the vein (visible with } \\
\text { hand lens). All Polytrichales }\end{array}$ & $\begin{array}{l}\text { Polytrichastrum alpinum, } \\
\text { Polytrichum commune }\end{array}$ \\
\hline sc & Small cushion & $\begin{array}{l}\text { Dome-shaped colonies }<5 \mathrm{~cm} \\
\text { deep. Shoots grow from a central } \\
\text { point with limited growth. }\end{array}$ & $\begin{array}{l}\text { Andreaea rupestris, Schistidium } \\
\text { apocarpum, Grimmia spp. }\end{array}$ \\
\hline LC & $\begin{array}{l}\text { Large } \\
\text { cushion }\end{array}$ & $\begin{array}{l}\text { Dome-shaped colonies }>5 \mathrm{~cm} \\
\text { deep. Colonies may reach a radius } \\
\text { of several decimeters. }\end{array}$ & $\begin{array}{l}\text { Racomitrium lanuginosum, } \\
\text { Anoectangium aestivum, } \\
\text { Dicranum elongatum }\end{array}$ \\
\hline SU & $\begin{array}{l}\text { Short } \\
\text { unbranched } \\
\text { turf }\end{array}$ & $\begin{array}{l}\text { Colonies of unbranched (or sparsely } \\
\text { branched) erect shoots. Shoots }<5 \\
\mathrm{~cm} \text {. }\end{array}$ & $\begin{array}{l}\text { Aulacomnium turgidum, } \\
\text { Dicranum acutifolium, Cinclidium } \\
\text { stygium }\end{array}$ \\
\hline TU & $\begin{array}{l}\text { Tall } \\
\text { unbranched } \\
\text { turf }\end{array}$ & $\begin{array}{l}\text { Colonies of unbranched (or sparsely } \\
\text { branched) erect shoots. Shoots }>5 \\
\mathrm{~cm} \text {. }\end{array}$ & $\begin{array}{l}\text { Dicranum majus, D. scoparium, } \\
\text { Plagiomnium ellipticum, } \\
\text { Paludella squarrosa }\end{array}$ \\
\hline De & Dendroids & $\begin{array}{l}\text { Main stem creeping and becomes } \\
\text { erect. Branching stems from apex } \\
\text { of main stem. }\end{array}$ & $\begin{array}{l}\text { Climacium dendroides, } \\
\text { Thamnobryum alopecurum }\end{array}$ \\
\hline We & Weft & $\begin{array}{l}\text { Shoots grow erect and horizontally. } \\
\text { Multiple branching stems } \\
\text { distributed throughout the main } \\
\text { stem. Sometimes appearance of a } \\
\text { feather. }\end{array}$ & $\begin{array}{l}\text { Hylocomium splendens, } \\
\text { Pleurozium schreberi }\end{array}$ \\
\hline Ma & Mat & $\begin{array}{l}\text { Branched shoots grow horizontal to } \\
\text { substrate. Sometimes shoots } \\
\text { possess erect lateral branches. }\end{array}$ & $\begin{array}{l}\text { Hypnum cupressiforme, } \\
\text { Plagiothecium denticulatum }\end{array}$ \\
\hline BT & $\begin{array}{l}\text { Branched } \\
\text { turf }\end{array}$ & $\begin{array}{l}\text { Colonies of erect shoots with some } \\
\text { branching. }\end{array}$ & $\begin{array}{l}\text { Tomentypnum nitens, } \\
\text { Racomitrium spp., } \\
\text { Drepanocladus revolvens }\end{array}$ \\
\hline
\end{tabular}


the mat a rougher surface as described by Bates (1998), but generally the branched shoots lie flat on the surface and, therefore, have a rather compact appearance. Mats are often found on solid substrates like logs or stones. Branched turf forms a new group containing pleurocarp and cladocarp forming turfs. Like the unbranched turf, they have erect shoots but differ in that their shoots are branched, although usually not as branched as the Wefts. The abundant tundra species Tomentypnum nitens (Hedw.) Loeske and species from the Racomitrium genus belong to this group.

The 12 BFGs (Fig. 2) do not encompass all tundra bryophyte species but focus on the perennial bryophytes, which constitute the vast majority of species (in the British bryophyte flora, $90 \%$ of species are perennial, Hill et al. 2007). Most species can be ascribed to only one BFG but some variable species will have a primary and a secondary life form, as recognized by Hill et al. (2007). For example, the cladocarpous Racomitrium lanuginosum is often quite branched and can form continuous and often deep layers, which would place it in the "branched turf" group. In more exposed sites with less vegetation cover, it can form dense cushions and would therefore be better placed within the "Large cushion" group. Furthermore, although species within each BFG do not necessarily share all characteristics (Dormann and Woodin 2002; Dorrepaal 2007) we argue that our bryophyte functional groups will increase resolution in tundra ecosystem studies compared with the frequent lumping of all bryophytes into one or very few functional groups.

\section{Ecosystem functions of the BFGs}

We assessed whether our choice of field-identifiable bryophyte functional groups can lead to a more meaningful representation of tundra bryophytes in the study of their ecosystem function by investigating how the groups separate for one key trait that is frequently measured, the WHC. As such, if BFGs separate into more than one cluster, we can conclude that the resolution for that trait is improved compared with the commonly used "bryophytes". Currently bryophyte trait data are poorly represented in global and regional trait databases such as the TRY (Kattge et al. 2020) and the tundra plant specific Tundra Trait Team database (Bjorkman et al. 2018), which limits the possibility to fully test the BFGs. However, a wide set of ecosystem functions are ultimately linked to bryophyte water balance. Water content, in turn, depends on habitat, seasonal climate and the speciesspecific ability of bryophytes to retain and hold water. The trait WHC is determined by a set of other traits, such as colony density, and leaf and shoot morphology (Elumeeva et al. 2011). Water content is important for key bryophyte traits such as insulation capacity, albedo, flammability, growth and association with $\mathrm{N}_{2}$-fixing bacteria (Cornelissen et al. 2007; May et al. 2018).

To assess if our groups indeed perform better than those previously identified, we also compared our groups with three previous grouping systems. We chose the life form classification by Grace (1995), as this has been tested on non-expert people and found to be user-friendly, and it is most similar to our groups with Sphagnum defined as a separate group, "whorled branched turf". We included the primary life forms as defined by Bernhardt-Römermann et al. (2018), because these are the most recent of the life form classifications. As a third grouping system, we included perichaetial position (La Farge-England 1996), with the only adaptation that we included liverworts as a separate group.

\section{WHC data collection and analysis}

We collated existing data on WHC, defined as maximum water held per gram of dry mass of bryophyte shoots or monospecific bryophyte colonies. The full data set included 1360 observations of 59 species from both published and unpublished studies. All data were from tundra ecosystems, except one Norwegian coastal heathland study (S.B. Rui, 
V. Vandvik, and S. Haugum, unpublished data, 2018). Although the method across studies did not follow any standardized protocol the studies could be grouped into three methods of measuring WHC, as "internally" (Shoot $\left.{ }_{\text {int }}\right)$ and "internal and externally" (Shoot ${ }_{\text {int+ext }}$ ) held water in shoots and for whole bryophyte colonies (see Appendix Table A1 for the descriptions of methods for the individual studies). Although colonies represent the most realistic field situation, measurements at the shoot level are less destructive and, therefore, possible to conduct in long-term experimental plots and often data will, therefore, exist in this form. Internally held water is likely what directly links to physiological processes taking place inside bryophyte cells but is likely ultimately dependent on colony WHC. WHC Shoot ${ }_{\text {int }}$ data included 36 species representing 7 BFGs (Elumeeva et al. 2011; Michel et al. 2012; Roos et al. 2019; van Zuijlen et al. 2021). WHC Shoot ${ }_{\text {int+ext }}$, data included 28 species representing 8 BFGs (S.B. Rui, V. Vandvik, and S. Haugum, unpublished data, 2018; Elumeeva et al. 2011; A.M. Rzepczynska, A. Michelsen, and S. Lett, unpublished data, 2019) and WHC colony data included 33 species representing 7 BFGs (Elumeeva et al. 2011; I.S. Jónsdóttir, unpublished data, 2020; Lett et al. 2017; Liu and Rousk 2021; May et al. 2018; Michel et al. 2012; A.M. Rzepczynska, A. Michelsen, and S. Lett, unpublished data, 2019).

Correlation analyses with averaged species WHC values showed that WHC of whole colonies and WHC of Shoot int+ext $_{\text {Were well correlated (Fig. A2a), whereas WHC Shoot }}$ int did not correlate with other ways of measuring WHC (Fig. A2b, c). Data for WHC Shoot int was, therefore, excluded from further analyses. The remaining data set included 963 observations of 37 bryophyte species, which we assigned to eight different BFGs (Fig. 3, Fig. A3) and to existing grouping schemes, namely "perichaetial position" (Liverworts grouped separately) (La Farge-England 1996), life form according to Grace (1995) and life form according to the BryForTrait database (Bernhardt-Römermann et al. 2018). Differences in WHC between groups within the different grouping schemes were analyzed with a mixed-effect model followed by Tukey's HSD test (see Appendix A). All data were handled and analyzed in $\mathrm{R}$ version 4.0.3 ( $\mathrm{R}$ Core Team 2020).

\section{Tundra bryophyte functional groups in relation to WHC}

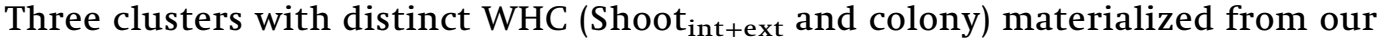
analysis (Fig. 3). "Sphagnum" had the highest WHC, with an average of $17 \mathrm{~g}$ water per g dry weight for colonies and Shoot ${ }_{\text {int+ext }}$. The high WHC of Sphagnum species is primarily attributed to their specialized hyaline cells, which greatly increase their water holding capacity. With $2 \mathrm{~g} / \mathrm{g}$, "Polytrichales" had the lowest WHC and there was little variation between species within the group. Polytrichales are unique in several ways as they have relatively well-developed water conducting tissue and root-like structures, rhizoids and waxy leaves, a feature that reduces water evaporation rather than increasing water storage. The four groups, "Weft", "Mats", "Tall and Short unbranched turf", and "Branched turf" had intermediate WHC and did not differ from each other. Large variation between species within those groups (Fig. A3) shows that not all our groups distinguish themselves from each other in terms of WHC. Particularly the groups "Short unbranched turf" and "Tall unbranched turf" displayed almost as much variation between species within groups as the entire spectrum of the data set. A better separation between those groups might have been achieved by use of standardized protocols or a larger number of species representing each group. However, the groups possibly differ in other functional traits and thus represent functionally distinct species clusters, and this should be tested in future work.

Four of our groups were not represented in the analyses. Of these, "Thalloid" is, with its absence of leaves, the morphologically most distinct. From this group Marchantia foliacea Mitt. and Monoclea forsteri Hook. from New Zealand forests had WHC of 20 and $10 \mathrm{~g} / \mathrm{g}$, respectively (Green and Snelgar 1982), which is within the upper end the spectrum covered 
Fig. 3. Water holding capacity (WHC, g water per g dry mass bryophyte, g/g) analyzed across each of four grouping schemes. Black dots are species means and grey diamonds are group means. The data set includes 963 observations of 37 species. Each species was assigned a bryophyte functional group (BFG), perichaetial position (La FargeEngland 1996), and life form according to Bernhardt-Römermann (2018), and life form following Grace (1995). BFGs are represented in the data set by Po, Polytrichales; BT, Branched turf; LL, Leafy liverworts; We, Weft; SU, Short unbranched turf; TU, Tall unbranched turf; Ma, Mat; Sp, Sphagnum). BryForTrait Life form following Bernhardt-Römermann et al (2018) are represented by Weft, Mat, Turf, cushion and species not assigned to groups (NA). Life form following Grace (1995) are represented by Large (L) cushion, Smooth mat, Tall (T) turf, Short (S) turf, Weft, Rough (R) mat, and Whorled branch (WB) turf. Groups with different lower-case letters are significantly different, N.S. indicate where groups that are not different (Tukey's HSD test, $p<0.05$ ). Full variation within species for each BFG can be seen in the Appendix Fig. A3.
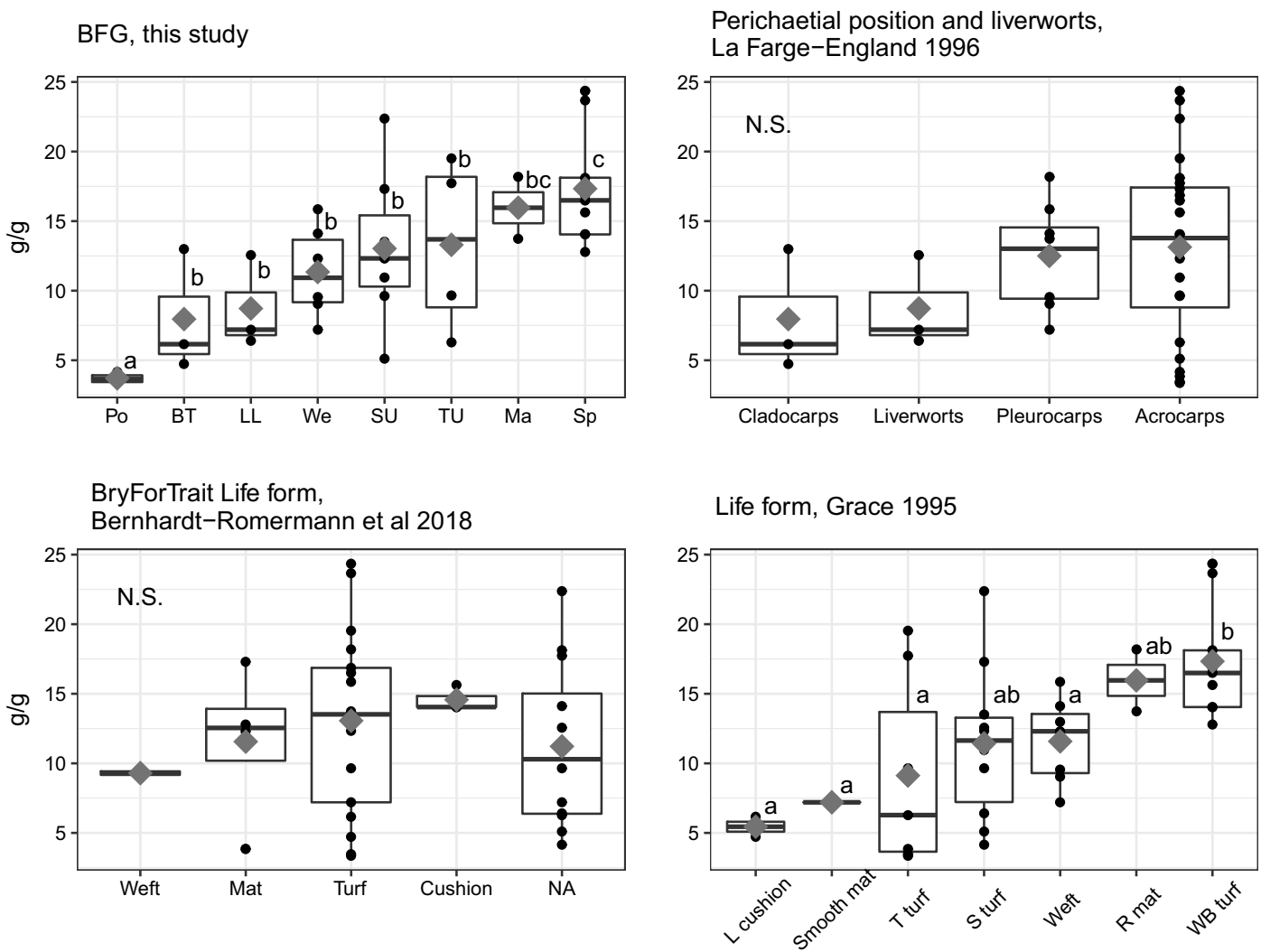

in our study. "Cushions", large and small, were also not represented by our data. Cushion growth is considered an adaptation to water conservation and low temperatures (Rice and Schneider 2004; Sand-Jensen and Hammer 2012). The WHC of "Dendroid" bryophytes has not been studied but the dendroid life form is associated with habitats of relatively high moisture or humidity (Atherton et al. 2010). Dendroids grow in loose patches, often intermingled with other species, and with limited branches at the lower stem, which could suggest that their WHC is not improved by colony structure.

\section{Tundra bryophyte functional groups and other functional traits}

Data at the species level for more than one functional trait are required to fully understand the functional roles of each BFG. Water holding capacity is only one of many important traits which relate bryophytes to key ecosystem functions (Cornelissen et al. 2007), and the BFGs are likely to cluster in unique ways for different functional traits. Here, we 
Fig. 4. Selection of six bryophyte traits important for ecosystem functioning and their estimated relative value across the 12 bryophyte functional groups (BFGs). Three shades of green, light to dark indicate relative trait values (low, intermediate, high) assessed from the referenced sources (Furness and Grime 1982a; Lang et al. 2009; Elumeeva et al. 2011; Soudzilovskaia et al. 2013; Lett et al. 2017; Roos et al. 2019; A.M. Rzepczynska, A. Michelsen, and S. Lett, unpublished data, 2019). Diagonally split cells reflect that for a given BFG trait values range across the full spectrum. Striped cells are not covered by the given reference but are hypothesized based on authors' expert knowledge, no propositions are made for white cells; question marks indicate lack of data. Traits are water holding capacity (WHC), colony density, bryophyte colony layer depth/ shoot length, growth rate, tissue decomposability and nitrogen $(\mathrm{N})$ content. References for a given trait do not necessarily use common protocols or units. No study covers all traits or all BFGs. Bryophyte functional groups are Sp, Sphagnum; De, Dendroid; We, Weft; Ma, Mat; BT, Branched turf; SC, Small cushion; LC, Large cushion; SU, Short unbranched turf; TU, Tall unbranched turf; Po, Polytrichales; LL, Leafy liverworts; Th, Thalloid.

\begin{tabular}{|c|c|c|c|c|c|c|c|c|c|c|c|c|c|}
\hline \multirow[b]{2}{*}{ Trait } & \multicolumn{12}{|c|}{ Bryophyte functional groups - BFGs } & \multirow[b]{2}{*}{ Reference } \\
\hline & $\mathrm{Sp}$ & $\mathrm{De}$ & We & $\mathrm{Ma}$ & BT & SC & LC & SU & TU & Po & LL & Th & \\
\hline WHC & & $?$ & & & & $?$ & $?$ & & & & & $?$ & This study \\
\hline $\begin{array}{l}\begin{array}{l}\text { Colony } \\
\text { density }\end{array} \\
\end{array}$ & & $?$ & & $?$ & & $?$ & & & & & & ? & \begin{tabular}{|l} 
Soudzilovkaia et al. 2013, Lett et al. 2017 \\
Elumeeva et al. 2011
\end{tabular} \\
\hline \begin{tabular}{|l|} 
Depth/ \\
shoot length
\end{tabular} & & $?$ & & & & & & & & & & ? & Soudzilovkaia et al. 2013 \\
\hline Growth rate & & & & & & $?$ & $?$ & & & & & $?$ & \begin{tabular}{|l|} 
Furness and Grime 1982a, Rzepczynska, \\
Michelsen, Lett, unpublished data.
\end{tabular} \\
\hline \begin{tabular}{|l|} 
Decom- \\
posability
\end{tabular} & & $?$ & & $?$ & & $?$ & $?$ & & & & & & Lang et al. 2009 \\
\hline $\mathrm{N}$ content & & $?$ & & ? & & $?$ & $?$ & & & & & $?$ & \begin{tabular}{|l|} 
Roos et al. 2019, Rzepczynska, \\
Michelsen. Lett. unpublished data.
\end{tabular} \\
\hline
\end{tabular}

discuss how additional functional traits, which are presumed to be of importance for ecosystem functioning, likely differ between the BFGs, i.e., colony density, bryophyte layer depth, relative growth rate, decomposability, and nutrient content, and identify the need for further research (Fig. 4).

Colony density together with bryophyte layer depth affect soil insulation efficiency, which in turn affects soil temperature, organic matter decomposition, nutrient cycling, active layer depth, and permafrost (Gornall et al. 2007; Soudzilovskaia et al. 2013). Colony density is relatively low in "Sphagnum", "Weft", and "Tall unbranched turf", whereas "Branched turf" and "Polytrichales" are BFGs that often have relatively higher density values (Fig. 4). Bryophyte layer depth or mat thickness is here defined as the distance from bryophyte layer surface to the point where bryophyte shoots or thalli begin to disintegrate. Mat thickness differs between some BFGs partly because size is an explicit character defining some groups ("Unbranched turf" and "Cushion"). Along with "Sphagnum", "Tall unbranched turf" and "Large cushion" create relatively deep bryophyte layers (Fig. 4). "Thalloid" bryophytes and "Mats" are never deep as they grow in close contact with the substrate.

The contribution of bryophytes to ecosystem $\mathrm{C}$ balance is manifested by the bryophyte layer depth as the balance between their net primary production and litter decomposability leads to variation in accumulation of bryophyte-derived organic matter. Both growth rate and decomposability show high variation between species and potentially between the BFGs. Studies comparing growth rates between multiple bryophyte species are relatively sparse and likely very sensitive to the method used. In growth chambers, length increment of "Sphagnum" was high compared with intermediate "Weft" and "Branched turf" and "Unbranched turf" and slow growing "Leafy liverworts" (Fig. 4, A.M. Rzepzynska, A. Michelsen, and S. Lett, unpublished data, 2019), whereas maximum biomass gain under 
highly standardized conditions was the highest in "Short unbranched turf" and "Leafy liverworts" (Furness and Grime 1982a). Although both length and biomass gain may be relevant performance indicators, they are two different functional traits (Furness and Grime 1982b). This highlights the need for standardized bryophyte trait protocols. Bryophyte functional groups seem to have a relatively high variability in decomposability as "Sphagnum" had the lowest decomposition rates, followed by "Thalloid" bryophytes and "Branched turfs" (Fig. 4, Lang et al. 2009). "Unbranched turf", "Weft" and "Polytrichales" had intermediate decomposition rates, and "Leafy liverworts" had the highest decomposition rates. The rates of these two processes are likely influenced mostly by the contents of C-rich recalcitrant compounds, but also by tissue nutrient contents. Both bryophyte growth and decomposability are likely to be strongly affected by tissue nutrient content (Lang et al. 2009), and $\mathrm{N}$ content can be regarded as a separate functional trait.

Although there are indications from previous studies that BFGs are likely to differ in important functional traits (Fig. 4), there are big gaps in available data and the BFGs are not evenly represented. "Dendroids", "Mats", "Small and large cushion" and "Thalloids" are heavily understudied and focused efforts to include species representing these groups is crucial. In addition, there is a range of other important functional bryophyte traits which are less studied. For example, flammability has large impacts on ecosystem $\mathrm{C}$ and $\mathrm{N}$ balance and could become more important under future warmer and drier climate conditions. As water content greatly influences bryophyte flammability (Blauw et al. 2015), flammability could be linked to WHC and, thus, predicted by the BFGs. Bryophytes constitute an important substrate in many tundra ecosystems for $\mathrm{N}_{2}$-fixing bacteria with substantial interspecies variation (Gavazov et al. 2010; Stuart et al. 2020). The mechanisms controlling $\mathrm{N}_{2}$ fixation in bryophytes are poorly understood but traits like WHC and perhaps specific leaf area are potential important predictors of species differences (S. Lett, C.T. Christiansen, E. Dorrepaal, and A. Michelsen, unpublished data, 2018; Liu and Rousk 2021). In conclusion, the BFGs are likely to have unique combinations of trait values for a range of functional traits and the application of BFG could improve functional resolution in ecosystem studies.

Although BFGs may differ in one or many functional traits, many traits are plastic and may cause substantial intraspecific (or intra-BFG) variation. This variation needs to be further explored and it is possible that for some traits, the extent of the intraspecific variation may be predicted by the BFGs. For example, the trait "bryophyte albedo" is highly plastic for some species e.g., within the genera of Sphagnum and Racomitrium, which turn whiteish upon drought (May et al. 2018). In addition, trait plasticity could be important for understanding changes in bryophyte community composition in relation to environmental change as species or BFGs with higher trait plasticity may be less susceptible to environmental changes (Henn et al. 2018; Roos et al. 2019).

\section{Using BFGs in vegetation surveys}

The inclusion of bryophyte functional groups in vegetation assessments using standard methods such as the point-intercept method, a standard within the International Tundra Experiment (ITEX) network (Molau and Mølgaard 1996), and visual cover estimates could improve vegetation analyses in tundra ecosystems by providing greater resolution of the bryophyte component in plant communities. The BFGs are partly defined by the type of colony they appear in, but bryophytes do not always grow in monospecific patches. Often, they grow in complex assemblages of multiple species, which may or may not belong to the same functional group. If species growing in the same colony do not belong to the same BFG, how should a BFG then be determined based on colony type? For the point intercept method, this is partly solved in our classification system which combines shoot and colony 
characteristics. The hierarchical organization (Fig. 2) of the BFGs allows group determination at a "lower" level in cases where colony type cannot be determined (Broad functional groups, Fig. 2). For visual cover estimates of bryophyte colonies, the BFG that the dominating species belongs to may be recorded. In relation to these issues, functional properties of mixed and single species bryophyte colonies can differ beyond the additive effect of the combination of species (Mulder et al. 2001; Rixen and Mulder 2005; Michel et al. 2012). In this way, the function of a given colony may not be the weighted mean of the species present in the colony. This is especially an issue when assessing bryophyte community function based on the species present in the ecosystem. Functional groups, like the ones suggested here, do not eliminate this issue. Despite these unresolved situations, we believe that the benefits of using BFGs will exceed the drawbacks.

In practice, we suggest using the proposed bryophyte functional group classification as a complement to the species approach. Thus, when a species cannot be determined due to issues such as time or skill limitation, hits are assigned to the group. It may also be advisable for field researchers to learn the two to three most common species in their plots and go to species level here. Importantly, the BFGs could also be used the "other way around" as a means to combine species allowing comparison of bryophyte-cover data across experiments and field sites. This type of aggregation is essential for enabling comparison when sites do not have the same species and has been done successfully for vascular plants within the ITEX network (Walker et al. 2006; Elmendorf et al. 2012a, 2012b). This would provide important insights into the responses of bryophyte communities to climate and environmental change and their ecosystem impacts and consequences.

\section{Directions for future research}

The BFGs suggested here are a first step to facilitate inclusion of bryophytes in vegetation surveys at a higher functional resolution than simply "bryophytes", while still accessible to non-experts and a means to lump bryophytes into meaningful groups that share important functional traits. However, the suggested BFGs need to be further evaluated for their usefulness by statistical testing for additional traits measured at the species level. With the WHC data, we provide an example of how this evaluation can be done and show that for WHC bryophyte functional resolution is increased from one to three by using the BFGs rather than the generic "bryophytes" and that the BFGs explain WHC better than previous grouping systems. The outcome might either support the grouping suggested here or require adjustments.

Further testing of the BFGs requires accessible functional trait data, which is currently limited. To allow robust analyses, these traits must be gathered using standardized protocols building on previous efforts (Jónsdóttir et al. 1999; Cornelissen et al. 2007; Hill et al. 2007). To improve or include bryophyte representation in current trait databases such as TRY and Tundra Trait Team (Kattge et al. 2020; Bjorkman et al. 2018), bryophyte functional trait data need to be geographically and taxonomically diverse for good representation of species. Unlike vascular plants, bryophyte functional traits are rarely recorded in field experiments, as this requires skills in species identification. For instance, in the database TRY, moss shoot length only has 716 entries and none of the observations are georeferenced, whereas vascular plant height has 249,551 observations (Kattge et al. 2020) and Arctic plant traits are generally highly under-represented (Bjorkman et al. 2018). Future challenges, therefore, lie in identifying and measuring bryophyte traits that underpin key ecological functions and to add these to existing trait databases. Importantly, species-level identification cannot be circumvented for these trait studies.

Bryophyte species identification will likely remain a struggle for many ecologists. This is further challenged by the lack of a comprehensive flora covering the Arctic region and poor 
representation of bryophytes in plant-identification mobile phone applications such as SEEK-iNaturalist or PictureMe (the authors, personal observation). To date, there is not a comprehensive bryophyte flora that covers Greenland and North America. Fennoscandia and the Russian Arctic are covered by several regional floras (Table A2). As the Arctic biome consists of many countries, language can be another obstacle for identification. Comprehensive floras are needed to facilitate further focus on tundra ecosystem functioning where bryophytes are a major component both in terms of biomass, primary production and diversity. In the longer term, novel field-based genetic profiling technology (Parker et al. 2017) and plant identification applications may develop to become powerful tools for aiding field identification. Until then, our contribution seeks to minimize the loss of data in the long-term monitoring of the Arctic vegetation and elucidate the functional role and importance of bryophytes in tundra ecosystems. This may, in turn, stimulate further focus on species identification as well as facilitate openings for innovative research projects.

\section{Final remarks}

Today, bryophytes constitute a missing functional and evolutionary dimension in most tundra ecosystem studies, hindering our ability to understand ecosystem functionality and responses to environmental change. Using BFGs could be a means to include functional diversity of bryophytes in ecological studies while bypassing difficulties with species identification. Our example with bryophyte WHC shows some of the potentials and challenges of using BFGs and the groups can likely be improved through further studies at the species level. If proven robust, the groups could likely be expanded to include the boreal zone, another region where bryophytes play a major role (Turetsky et al. 2012). The hierarchical organization of the BFGs allows functional resolution to be adjusted to the scientific question in mind. Importantly, our suggestion to use the BFGs in ecological studies is not a suggestion to abandon studies of bryophyte functionality and responses at the species level. Rather it should be seen as an encouragement to include bryophytes at a higher functional resolution than simply "bryophyte" in more studies.

\section{Contributors' statement}

SL and ISJ conceived the original idea for the paper, which was developed with input from ABS, CTC, HD, FE, GHRH, SIL, AM, KR. ISJ, SB, SL, TGE, XL, JM, AMR, KvZ contributed data. SL analyzed the data and led the writing of the paper. All authors contributed to writing and editing of the manuscript.

\section{Acknowledgements}

This study was supported by a grant to SL from the European Union's Horizon 2020 research and innovation programme under the Marie Sklodowska-Curie, Grant No. 797446 and by the Independent Research Fund Denmark, Grant no. 0135-00140B. Funding from the Academy of Finland (grant 322266), National Science Foundation (1504224, 1836839, PLR-1504381 and PLR-1836898), Independent Research Fund Denmark (904000314B), Moscow State University, (project No 121032500089-1), Natural Sciences and Engineering Research Council of Canada, ArcticNet, Polar Continental Shelf Program, Northern Science Training Program, Polar Knowledge Canada, Royal Canadian Mounted Police, Tomsk State University competitiveness improvement program and the Russian Science Foundation (grant No 20-67-46018) are gratefully acknowledged. Matthias Ahrens provided valuable insights on the cushion growth form, and we are most thankful. We thank Gaius Shaver and two anonymous reviewers for providing valuable critique and input to earlier versions of this manuscript. 


\section{References}

Atherton, I., Bosanquet, S.D.S., and Lawey, M. 2010. Mosses and liverworts of Britain and Ireland: a field guide. British Bryological Society.

Austrheim, G., Hassel, K., and Mysterud, A. 2005. The role of life history traits for bryophyte community patterns in two contrasting alpine regions. Bryologist, 108: 259-271. doi: 10.1639/0007-2745(2005)108[0259:TROLHT]2.0.CO;2.

Bates, J.W. 1998. Is “Life-Form” a useful concept in bryophyte ecology? Oikos, 82: 223-237. doi: 10.2307/3546962.

Bernhardt-Römermann, M., Poschlod, P., and Hentschel, J. 2018. BryForTrait - A life-history trait database of forest bryophytes. J. Veg. Sci. 29: 798-800. doi: 10.1111/jvs.12646.

Bintanja, R., and Andry, O. 2017. Towards a rain-dominated Arctic. Nature Clim. Change, 7: 263-267.doi: 10.1038/ nclimate3240.

Bjorkman, A.D., Myers-Smith, I.H., Elmendorf, S.C., Normand, S., Thomas, H.J.D., Alatalo, J.M., et al. 2018. Tundra Trait Team: A database of plant traits spanning the tundra biome. Global Ecol. Biogeogr. 27: 1402-1411. doi: 10.1111/geb.12821.

Bjørkvoll, E., Pedersen, B., Hytteborn, H., Jónsdóttir, I.S., and Langvatn, R. 2009. Seasonal and interannual dietary variation during winter in female Svalbard reindeer (Rangifer tarandus platyrhynchus). Arctic, Antarctic, Alpine Res. 41: 88-96. doi: 10.1657/1523-0430-41.1.88.

Blauw, L.G., Wensink, N., Bakker, L., van Logtestijn, R.S.P., Aerts, R., Soudzilovskaia, N.A., and Cornelissen, J.H.C. 2015. Fuel moisture content enhances nonadditive effects of plant mixtures on flammability and fire behavior. Ecol. Evol. 5: 3830-3841. doi: 10.1002/ece3.1628. PMID: 26380709.

Blok, D., Heijmans, M.M.P.D., Schaepman-Strub, G., van Ruijven, J., Parmentier, F.J.W., Maximov, T.C., and Berendse, F. 2011. The cooling capacity of mosses: Controls on water and energy fluxes in a Siberian tundra site. Ecosystems, 14: 1055-1065. doi: 10.1007/s10021-011-9463-5.

Brodribb, T.J., Carriquí, M., Delzon, S., McAdam, S.A.M., and Holbrook, N.M. 2020. Advanced vascular function discovered in a widespread moss. Nat. Plants, 6: 273-279. doi: 10.1038/s41477-020-0602-x. PMID: 32170283.

Cooper, E.J., Little, C.J., Pilsbacher, A.K., and Mörsdorf, M.A. 2019. Disappearing green: Shrubs decline and bryophytes increase with nine years of increased snow accumulation in the High Arctic. J. Veg. Sci. 30: 857-867. doi: 10.1111/jvs.12793.

Cornelissen, J.H.C., Lang, S.I., Soudzilovskaia, N.A., and During, H.J. 2007. Comparative cryptogam ecology: a review of bryophyte and lichen traits that drive biogeochemistry. Ann Bot 99: 987-1001. doi: 10.1093/aob/mcm030. PMID: 17353205.

Díaz, S., and Cabido, M.R. 2001. Vive la différence: Plant functional diversity matters to ecosystem processes. Trends Ecol. Evol. 16(11): 646-655. doi: 10.1016/S0169-5347(01)02283-2.

Dormann, C.F., and Woodin, S.J. 2002. Climate change in the Arctic: using plant functional types in a meta-analysis of field experiments. Funct. Ecol. 16: 4-17. doi: 10.1046/j.0269-8463.2001.00596.x.

Dorrepaal, E. 2007. Are plant growth-form-based classifications useful in predicting northern ecosystem carbon cycling feedbacks to climate change? J. Ecol. 95: 1167-1180. doi: 10.1111/j.1365-2745.2007.01294.x.

Dorrepaal, E., Aerts, R., Cornelissen, J.H.C., Callaghan, T.V., and Logtestijn, R.S.P.V. 2004. Summer warming and increased winter snow cover affect Sphagnum fuscum growth, structure and production in a sub-arctic bog. Global Change Biol. 10: 93-104. doi: 10.1111/j.1365-2486.2003.00718.x.

Douma, J.C., Van Wijk, M.T., Lang, S.I., and Shaver, G.R. 2007. The contribution of mosses to the carbon and water exchange of arctic ecosystems: quantification and relationships with system properties. Plant, Cell Environ. 30: 1205-1215. doi: 10.1111/j.1365-3040.2007.01697.x. PMID: 17727412.

During, H.J. 1979. Life strategies of bryophytes: A preliminary review. Lindbergia, 5: 2-18.

During, H.J. 1992. Ecological classification of bryophytes and lichens. In Bryophytes and lichens in a changing environment. Edited by J.W. Bates and A.M. Farmer. Claredon Press, Oxford, UK.

Edwards, M., and Henry, G.H.R. 2016. The effects of long-term experimental warming on the structure of three High Arctic plant communities. J. Veg. Sci. 27: 904-913. doi: 10.1111/jvs.12417.

Elmendorf, S.C., Henry, G.H.R., Hollister, R.D., Björk, R.G., Bjorkman, A.D., Callaghan, T.V., et al. 2012a. Global assessment of experimental climate warming on tundra vegetation: heterogeneity over space and time. Ecol. Lett. 15: 164-175. doi: 10.1111/j.1461-0248.2011.01716.x.

Elmendorf, S.C., Henry, G.H.R., Hollister, R.D., Björk, R.G., Boulanger-Lapointe, N., Cooper, E.J., et al. $2012 b$. Plot-scale evidence of tundra vegetation change and links to recent summer warming. Nature Clim. Change, 2: 453-457. doi: 10.1038/nclimate1465.

Elumeeva, T.G., Soudzilovskaia, N.A., During, H.J., and Cornelissen, J.H.C. 2011. The importance of colony structure versus shoot morphology for the water balance of 22 subarctic bryophyte species. J. Veg. Sci. 22: 152-164.doi: 10.1111/j.1654-1103.2010.01237.x.

Furness, S.B., and Grime, J.P. 1982a. Growth Rate and Temperature Responses in Bryophytes: II. A Comparative Study of Species of Contrasted Ecology. J. Ecol. 70: 525-536. Wiley, British Ecological Society. doi: 10.2307/2259920.

Furness, S.B., and Grime, J.P. 1982b. Growth Rate and Temperature Responses in Bryophytes: I. An Investigation of Brachythecium rutabulum. J. Ecol. 70: 513-523. doi: 10.2307/2259919.

Gavazov, K., Soudzilovskaia, N., van Logtestijn, R., Braster, M., and Cornelissen, J. 2010. Isotopic analysis of cyanobacterial nitrogen fixation associated with subarctic lichen and bryophyte species. Plant Soil, 333: 507-517. doi: 10.1007/s11104-010-0374-6.

Gavini, S.S., Suárez, G.M., Ezcurra, C., and Aizen, M.A. 2019. Facilitation of vascular plants by cushion mosses in high-Andean communities. Alp. Bot. 129: 137-148. doi: 10.1007/s00035-019-00222-6. 
Geffert, J.L., Frahm, J.P., Barthlott, W., and Mutke, J. 2013. Global moss diversity: spatial and taxonomic patterns of species richness. J. Bryol. 35: 1-11. doi: 10.1179/1743282012Y.0000000038.

Gimingham, C.H., and Robertson, E.T. 1950. Preliminary Investigations on the Structure of Bryophytic Communities. Trans. British Bryol. Soc. 1: 330-344. doi: 10.1179/006813850804878734.

Gimingham, C.H., and Birse, E.M. 1957. Ecological studies on growth-form in bryophytes: I. Correlations between growth-form and habitat. J. Ecol. 45: 533-545. doi: 10.2307/2256934.

Glime, J.M. 2006. Bryophytes and herbivory. Crypt. Bryol. 27: 191-203.

Glime, J.M. 2012. Chapter 1 - The Fauna: A place to call home. In Bryophyte Ecology, 1st ed. Ebook sponsored by Michigan Technological University and the International Association of Bryologists, available from https://digitalcommons.mtu.edu/bryophyte-ecology/.

Gornall, J.L., Jónsdóttir, I.S., Woodin, S.J., and van der Wal, R.2007. Arctic mosses govern below-ground environment and ecosystem processes. Oecologia, 153: 931-941. doi: 10.1007/s00442-007-0785-0. PMID: 17618466.

Gornall, J.L., Woodin, S.J., Jónsdóttir, I.S., and van der Wal, R. 2011. Balancing positive and negative plant interactions: how mosses structure vascular plant communities. Oecologia, 166: 769-782. doi: 10.1007/s00442011-1911-6. PMID: 21279654.

Grace, M.1995. A key to the growthforms of mosses and liverworts and guide to their educational value. J. Biol. Edu. 29: 272-278. doi: 10.1080/00219266.1995.9655460.

Green, T.G.A., and Snelgar, W.P. 1982. A comparison of photosynthesis in two thalloid liverworts. Oecologia, 54: 275-280. doi: 10.1007/BF00378404. PMID: 28311440.

Henn, J.J., Buzzard, V., Enquist, B.J., Halbritter, A.H., Klanderud, K., Maitner, B.S., et al. 2018. Intraspecific Trait Variation and Phenotypic Plasticity Mediate Alpine Plant Species Response to Climate Change. Front. Plant Sci. 9. doi: 10.3389/fpls.2018.01548.

Hill, M.O., Preston, C.D., Bosanquet, S.D.S., and Roy, D.B. 2007. BRYOATT - Attributes of British and Irish mosses, liverworts and hornworts. Centre for Ecology and Hydrology, Huntingdon, Cambridgeshire, UK.

Hübner, C.E. 2007. Spring stopover in the Arctic: implications for migrating geese and their food plants. University Centre in Svalbard, Norway.

Hudson, J.M.G., and Henry, G.H.R. 2010. High Arctic plant community resists 15 years of experimental warming. J. Ecol. 98: 1035-1041. doi: 10.1111/j.1365-2745.2010.01690.x.

Huemmrich, K.F., Gamon, J.A., Tweedie, C.E., Oberbauer, S.F., Kinoshita, G., Houston, S., et al. 2010. Remote sensing of tundra gross ecosystem productivity and light use efficiency under varying temperature and moisture conditions. Remote Sens. Environ. 114: 481-489. doi: 10.1016/j.rse.2009.10.003.

Huttunen, S., Bell, N., and Hedenäs, L. 2018. The Evolutionary Diversity of Mosses - Taxonomic Heterogeneity and its Ecological Drivers. Crit. Rev. Plant Sci. 37: 128-174. doi: 10.1080/07352689.2018.1482434.

Ihl, C., and Barboza, P.S. 2007. Nutritional value of moss for Arctic ruminants: a test with muskoxen. Wild, 71: 752-758.doi: $10.2193 / 2005-745$.

Jägerbrand, A.K., Alatalo, J.M., and Kudo, G. 2014. Variation in responses to temperature treatments ex situ of the moss Pleurozium schreberi (Willd. ex Brid.) Mitt. originating from eight altitude sites in Hokkaido, Japan. J. Bryol. 36: 209-216. doi: 10.1179/1743282014Y.0000000095.

Jaroszynska, F. 2019. Climate and biotic interactions - drivers of plant community structure and ecosystem functioning in alpine grasslands. University of Bergen, Bergen, Norway.

Jasmin, J.-N., Rochefort, L., and Gauthier, G. 2008. Goose grazing influences the fine-scale structure of a bryophyte community in arctic wetlands. Polar Biol. 31: 1043-1049. 10.1007/s00300-008-0443-y.

Jones, G.A., and Henry, G.H.R. 2003. Primary plant succession on recently deglaciated terrain in the Canadian High Arctic. J. Biogeogr. 30: 277-296. doi: 10.1046/j.1365-2699.2003.00818.x.

Jónsdóttir, I.S. 1984. Áhrif beitar á gróður Auðkúluheiðar. Náttúrufræđingurinn, 53: 19-40.

Jónsdóttir, I.S. 1991. Effects of Grazing on Tiller Size and Population Dynamics in a Clonal Sedge (Carex bigelowii). Oikos, 62: 177-188. doi: $10.2307 / 3545263$.

Jónsdóttir, I.S., Callaghan, T.V., and Lee, J.A. 1995. Fate of added nitrogen in a moss-sedge Arctic community and effects of increased nitrogen deposition. Sci. Total Environ. 160-161: 677-685. doi: 10.1016/0048-9697(95)04402-M.

Jónsdóttir, I.S., Crittenden, P.D., and Jägerbrand, A.K. 1999. Measuring growth rate in bryophytes and lichens. In Proceedings from the 9th ITEX Meeting January 5-9 1999. Michigan State University, East Lancing. pp. 91-95.

Jónsdóttir, I.S., Magnússon, B., Gudmundsson, J., Elmarsdóttir, Á., and Hjartarson, H. 2005. Variable sensitivity of plant communities in Iceland to experimental warming. Global Change Biol. 11: 553-563. doi: 10.1111/j.13652486.2005.00928.x.

Jonsson, M., Kardol, P., Gundale, M.J., Bansal, S., Nilsson, M.-C., Metcalfe, D.B., and Wardle, D.A. 2015. Direct and indirect drivers of moss community structure, function, and associated microfauna across a successional gradient. Ecosystems, 18: 154-169. doi: 10.1007/s10021-014-9819-8.

Jorgenson, M.T.J.T., Romanovsky, V.R., Harden, J.H., Shur, Y.S., O’Donnell, J.O., Schuur, E.A.G.S.A.G., et al. 2010. Resilience and vulnerability of permafrost to climate change. Can. J. For. Res. 40(7). doi: 10.1139/X10-060.

Kattge, J., Bönisch, G., Díaz, S., Lavorel, S., Prentice, I.C., Leadley, P., et al. 2020. TRY plant trait database - enhanced coverage and open access. Global Change Biol. 26: 119-188. doi: 10.1111/gcb.14904. PMID: 31891233.

Keuper, F., Dorrepaal, E., Van Bodegom, P.M., Aerts, R., Van Logtestijn, R.S.P., Callaghan, T.V., and Cornelissen, J.H.C. 2011. A race for space? How Sphagnum fuscum stabilizes vegetation composition during long-term climate manipulations. Global Change Biol. 17: 2162-2171. doi: 10.1111/j.1365-2486.2010.02377.x.

Kotanen, P.M., and Jefferies, R.L. 1997. Long-term destruction of sub-arctic wetland vegetation by lesser snow geese. Écoscience, 4: 179-182. doi: 10.1080/11956860.1997.11682393. 
La Farge-England, C. 1996. Growth form, branching pattern, and perichaetial position in mosses: Cladocarpy and pleurocarpy redefined. Bryologist, 99: 170-186. doi: 10.2307/3244546.

Lang, S.I., Cornelissen, J.H.C., Klahn, T., Van Logtestijn, R.S.P., Broekman, R., Schweikert, W., and Aerts, R. 2009. An experimental comparison of chemical traits and litter decomposition rates in a diverse range of subarctic bryophyte, lichen and vascular plant species. J. Ecol. 97: 886-900. doi: 10.1111/j.1365-2745.2009.01538.x.

Lang, S.I., Cornelissen, J.H.C., Shaver, G.R., Ahrens, M., Callaghan, T.V., Molau, U., et al. 2012. Arctic warming on two continents has consistent negative effects on lichen diversity and mixed effects on bryophyte diversity. Glob. Change Biol. 18: 1096-1107. doi: 10.1111/j.1365-2486.2011.02570.x.

Lavorel, S., McIntyre, S., Landsberg, J., and Forbes, T.D.A. 1997. Plant functional classifications: from general groups to specific groups based on response to disturbance. Trends Ecol. Evol. 12: 474-478. doi: 10.1016/S0169-5347(97) 01219-6. PMID: 21238163.

Lett, S., and Michelsen, A. 2014. Seasonal variation in nitrogen fixation and effects of climate change in a subarctic heath. Plant Soil, 379: 193-204. doi: 10.1007/s11104-014-2031-y.

Lett, S., Nilsson, M.-C., Wardle, D.A., and Dorrepaal, E. 2017. Bryophyte traits explain climate-warming effects on tree seedling establishment. J. Ecol. 105: 496-506. doi: 10.1111/1365-2745.12688.

Lett, S., Wardle, D.A., Nilsson, M., Teuber, L.M., and Dorrepaal, E. 2018. The role of bryophytes for tree seedling responses to winter climate change: Implications for the stress gradient hypothesis. J. Ecol. 106: 1142-1155. doi: 10.1111/1365-2745.12898.

Lett, S., Teuber, L.M., Krab, E.J., Michelsen, A., Olofsson, J., Nilsson, M.-C., Wardle, D.A., and Dorrepaal, E. 2020. Mosses modify effects of warmer and wetter conditions on tree seedlings at the alpine treeline. Global Change Biol. 26: 5754-5766. doi: 10.1111/gcb.15256. PMID: 32715578.

Lindo, Z., and Gonzalez, A. 2010. The bryosphere: An integral and influential component of the Earth's biosphere. Ecosystems, 13: 612-627. doi: 10.1007/s10021-010-9336-3.

Liu, X., and Rousk, K. 2021. The moss traits that rule cyanobacterial colonization. Ann. Bot.: mcab127. doi: 10.1093/ aob/mcab127.

Longton, R.E. 1988. The cryptogamic vegetation. In Biology of polar bryophytes and lichens. Cambridge University Press, New York, NY. pp. 32-65.

Mägdefrau, K. 1982. Life-forms of Bryophytes. In Bryophyte Ecology. Edited by A.J.E. Smith. 1st ed. Capman and Hall, NY, USA.

Mateo, R.G., Broennimann, O., Normand, S., Petitpierre, B., Araújo, M.B., Svenning, J.-C., et al. 2016. The mossy north: an inverse latitudinal diversity gradient in European bryophytes. Sci. Rep. 6: 25546. doi: 10.1038/ srep25546. PMID: 27151094.

Mauffrey, A.R.L., Cappelatti, L., and Griffin, J.N. 2020. Seaweed functional diversity revisited: Confronting traditional groups with quantitative traits. J. Ecol. 108: 2390-2405. doi: 10.1111/1365-2745.13460.

May, J.L., Parker, T., Unger, S., and Oberbauer, S.F. 2018. Short term changes in moisture content drive strong changes in Normalized Difference Vegetation Index and gross primary productivity in four Arctic moss communities. Remote Sens. Environ. 212: 114-120. doi: 10.1016/j.rse.2018.04.041.

Michel, P., Lee, W.G., During, H.J., and Cornelissen, J.H.C. 2012. Species traits and their non-additive interactions control the water economy of bryophyte cushions. J. Ecol. 100: 222-231. doi: 10.1111/j.1365-2745.2011.01898.x.

Molau, U., and Mølgaard, P. 1996. International Tundra Experiment (ITEX) Manual. Danish Polar Center, Copenhagen, Denmark.

Mulder, C.P.H., Uliassi, D.D., and Doak, D.F. 2001. Physical stress and diversity-productivity relationships: The role of positive interactions. PNAS, 98: 6704-6708. doi: 10.1073/pnas.111055298. PMID: 11371612.

Olofsson, J., Oksanen, L., Oksanen, T., Tuomi, M., Hoset, K.S., Virtanen, R., and Kyrö, K. 2014. Long-term experiments reveal strong interactions between lemmings and plants in the Fennoscandian highland tundra. Ecosystems, 17: 606-615. doi: 10.1007/s10021-013-9740-6.

Paradis, M., Lévesque, E., and Boudreau, S. 2016. Greater effect of increasing shrub height on winter versus summer soil temperature. Environ. Res. Lett. 11: 085005. doi: 10.1088/1748-9326/11/8/085005.

Parker, J., Helmstetter, A.J., Devey, D., Wilkinson, T., and Papadopulos, A.S.T. 2017. Field-based species identification of closely-related plants using real-time nanopore sequencing. Sci Rep 7: 8345. doi: 10.1038/s41598-017-08461-5. PMID: 28827531.

Proctor, M.C.F., and Tuba, Z. 2002. Poikilohydry and homoihydry: antithesis or spectrum of possibilities?. New Phytol. 156: 327-349. doi: 10.1046/j.1469-8137.2002.00526.x.

Proctor, M.C.F., Oliver, M.J., Wood, A.J., Alpert, P., Stark, L.R., Cleavitt, N.L., and Mishler, B.D. 2007. Desiccation-tolerance in bryophytes: a review. The Bryologist, 110: 595-621. doi: 10.1639/0007-2745(2007)110[595:DIBAR]2.0.CO;2.

Prop, J., and Vulink, T. 1992. Digestion by Barnacle Geese in the Annual Cycle: The Interplay Between Retention Time and Food Quality. Funct. Ecol. 6: 180-189. doi: 10.2307/2389753.

R Core Team. 2020. R: A language and environment for statistical computing. R Foundation for Statistical Computing, Vienna, Austria. Vienna, Austria. Available from https://www.R-project.org/.

Rice, S.K., and Schneider, N. 2004. Cushion size, surface roughness, and the control of water balance and carbon flux in the cushion moss Leucobryum glaucum (Leucobryaceae). Am. J. Bot. 91: 1164-1172. doi: 10.3732/ajb.91.8.1164. PMID: 21653472.

Rixen, C., and Mulder, C.P.H. 2005. Improved water retention links high species richness with increased productivity in arctic tundra moss communities. Oecologia, 146: 287-299. doi: 10.1007/s00442-005-0196-z. PMID: 16044351. 
Roos, R.E., van Zuijlen, K., Birkemoe, T., Klanderud, K., Lang, S.I., Bokhorst, S., et al. 2019. Contrasting drivers of community-level trait variation for vascular plants, lichens and bryophytes across an elevational gradient. Funct. Ecol. 33: 2430-2446. doi: 10.1111/1365-2435.13454.

Rousk, K., Sorensen, P.L., Lett, S., and Michelsen, A. 2015. Across-habitat comparison of diazotroph activity in the subarctic. Microb. Ecol. 69: 778-787. doi: 10.1007/s00248-014-0534-y. PMID: 25403111.

Rousk, K., Sorensen, P.L., and Michelsen, A. 2017. Nitrogen fixation in the High Arctic: a source of 'new' nitrogen? Biogeochemistry, 136: 213-222. doi: 10.1007/s10533-017-0393-y.

Russell, S. 1990. Bryophyte production and decomposition in tundra ecosystems. Bot. J. Linn. Soc. 104: 3-22. doi: 10.1111/j.1095-8339.1990.tb02208.x.

Sand-Jensen, K., and Hammer, K.J. 2012. Moss cushions facilitate water and nutrient supply for plant species on bare limestone pavements. Oecologia, 170: 305-312. doi: 10.1007/s00442-012-2314-z. PMID: 22481304

Soininen, E.M., Zinger, L., Gielly, L., Bellemain, E., Bråthen, K.A., Brochmann, C., et al. 2013. Shedding new light on the diet of Norwegian lemmings: DNA metabarcoding of stomach content. Polar Biol. 36: 1069-1076. doi: 10.1007| s00300-013-1328-2.

Solheim, B., and Zielke, M. 2003. Associations between cyanobacteria and mosses. Cyanobacteria in symbiosis, 137-152. Soudzilovskaia, N.A., Cornelissen, J.H.C., During, H.J., van Logtestijn, R.S.P., Lang, S.I., and Aerts, R. 2010. Similar cation exchange capacities among bryophyte species refute a presumed mechanism of peatland acidification. Ecology, 91: 2716-2726. doi: 10.1890/09-2095.1. PMID: 20957965.

Soudzilovskaia, N.A., Graae, B.J., Douma, J.C., Grau, O., Milbau, A., Shevtsova, A., et al. 2011. How do bryophytes govern generative recruitment of vascular plants? New Phytol. 190: 1019-1031. doi: 10.1111/j.1469-8137. 2011.03644.x. PMID: 21342202.

Soudzilovskaia, N.A., van Bodegom, P.M., and Cornelissen, J.H.C. 2013. Dominant bryophyte control over high-latitude soil temperature fluctuations predicted by heat transfer traits, field moisture regime and laws of thermal insulation. Funct. Ecol. 27: 1442-1454. doi: 10.1111/1365-2435.12127.

St. Martin, P., and Mallik, A.U. 2017. The status of non-vascular plants in trait-based ecosystem function studies. Perspect. in Plant Ecol. 27: 1-8. doi: 10.1016/j.ppees.2017.04.002.

Street, L.E., Stoy, P.C., Sommerkorn, M., Fletcher, B.J., Sloan, V.L., Hill, T.C., and Williams, M. 2012. Seasonal bryophyte productivity in the sub-Arctic: a comparison with vascular plants. Funct. Ecol. 26: 365-378. doi: 10.1111/ j.1365-2435.2011.01954.x.

Street, L.E., Jens-Arne, S., Martin, S., Victoria, S., Helene, D., Gareth, K.P., and Mathew, W. 2013. The role of mosses in carbon uptake and partitioning in arctic vegetation. New Phytol. 199: 163-175. doi: 10.1111/nph.12285.

Stuart, J.E.M., Holland-Moritz, H., Lewis, L.R., Jean, M., Miller, S.N., McDaniel, S.F., et al. 2020. Host identity as a driver of moss-associated $\mathrm{N}_{2}$ fixation rates in Alaska. Ecosystems, 24, 530-547. doi: 10.1007/s10021-020-00534-3.

Thomas, E.K., Castañeda, I.S., McKay, N.P., Briner, J.P., Salacup, J.M., Nguyen, K.Q., and Schweinsberg, A.D. 2018. A Wetter Arctic Coincident With Hemispheric Warming 8,000 Years Ago. Geophys. Res. Lett. 45: 10,637-10,647. doi: 10.1029/2018GL079517.

Thomas, H.J.D., Myers-Smith, I.H., Bjorkman, A.D., Elmendorf, S.C., Blok, D., Cornelissen, J.H.C., et al. 2019. Traditional plant functional groups explain variation in economic but not size-related traits across the tundra biome. Global Ecol. Biogeogr. 28: 78-95. doi: 10.1111/geb.12783. PMID: 31007605.

Turetsky, M.R. 2003. The role of bryophytes in carbon and nitrogen cycling. Bryologist, 106: 395-409. doi: $10.1639 / 05$.

Turetsky, M.R., Bond-Lamberty, B., Euskirchen, E., Talbot, J., Frolking, S., McGuire, A.D., and Tuittila, E.-S. 2012. The resilience and functional role of moss in boreal and arctic ecosystems. New Phytol. 196: 49-67. doi: 10.1111/j.14698137.2012.04254.x. PMID: 22924403.

Vanderpoorten, A., and Goffinet, B. 2009. Ecology. In Introduction to bryophytes. Cambridge University Press, Cambridge, UK. pp. 153-184

Wal, R.V.D., Sjögersten, S., Woodin, S.J., Cooper, E.J., Jónsdóttir, I.S., Kuijper, D., et al. 2007. Spring feeding by pinkfooted geese reduces carbon stocks and sink strength in tundra ecosystems. Global Change Biol. 13: 539-545. 10.1111/j.1365-2486.2006.01310.x.

Walker, D.A., and Raynolds, M.K. 2011. An International Arctic Vegetation Database: a foundation for panarctic biodiversity studies. Concept Paper. CAFF International Secretariat.

Walker, M.D., Wahren, C.H., Hollister, R.D., Henry, G.H.R., Ahlquist, L.E., Alatalo, J.M., et al. 2006. Plant community responses to experimental warming across the tundra biome. PNAS 103: 1342-1346. doi: 10.1073/pnas.0503198103. PMID: 16428292.

Wielgolaski, F.E. 1971. Vegetation types and primary production in tundra. In Proceedings IV International Meeting on the Biological Productivity of Tundra. Edited by F.E. Wiel and T. Roswall. The Tundra Steering Committee, Leningrad, USSR. pp. 9-34.

Woodin, S.J., van der Wal, R., Sommerkorn, M., and Gornall, J.L. 2009. Differential allocation of carbon in mosses and grasses governs ecosystem sequestration: ${ }^{13} \mathrm{C}$ tracer study in the high Arctic. New Phytol. 184: 944-949. doi: 10.1111/j.1469-8137.2009.03022.x. PMID: 19754640.

van Zuijlen, K., Klanderud, K., Knutsen, M.S., Dahle, O.S., Hasvik, Å., Sundsbø, S., Olsen, S.L., and Asplund, J. 2021. Community-level functional traits of alpine vascular plants, bryophytes and lichens after 19 years of experimental warming. Arct. Sci. doi: 10.1139/as-2020-0007.

van Zuijlen, K., Roos, R.E., Klanderud, K., Lang, S.I., Wardle, D.A., and Asplund, J. 2020. Decomposability of lichens and bryophytes from across an elevational gradient under standardized conditions. Oikos, 129: 1358-1368. doi: 10.1111/oik.07257. 


\section{Appendix A}

\section{Methodology for water holding capacity}

Water holding capacity (WHC) in all studies was measured as maximum held water per gram dry weight bryophyte. No recognized standardized protocol exists for measuring WHC and methodology therefore differed between studies (Table A2). However, across the WHC studies examined, three different general approaches were followed: WHC for Shoot $_{\text {int+ex }}$, WHC for Shoot ${ }_{\text {ext }}$ and WHC for colonies. Shoot ${ }_{\text {int+ext }}$ WHC was the weight difference of shoots at full water saturation and after complete drying. Shoot int $_{\text {WHC was }}$ measured in a similar manner except external water was removed before weighing by blotting shoots dry on a paper towel (Elumeeva et al. 2011). Bryophyte colony WHC was measured by weighing colonies at fully saturated conditions and after complete drying. For bryophyte colonies, volume varied between 20 and $3200 \mathrm{~cm}^{3}$ between studies, though one study had volumes down to $2.5 \mathrm{~cm}^{3}$ for some small statured bryophytes Neoorthocaulis floerkii, and Dicranum elongatum (A.M. Rzepczynska, A. Michelsen, and S. Lett, unpublished data, 2019).

To test if WHC measurements of the three approaches were correlated, we averaged species values and where species were represented for at least two approaches, these were

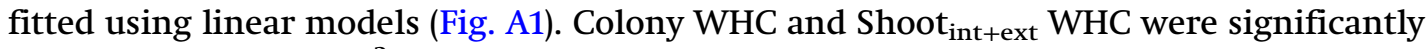
correlated $\left(p<0.001, R^{2}=0.70\right)$, whereas Shoot ${ }_{\text {int }}$ WHC did not correlate with colony or Shoot $_{\text {ext }}$ WHC (Figure A1). This suggests that WHC can be measured on single shoots (WHC of Shoot int+ext in permanent plots where destructive measurement must be kept to a minimum and still represent colony WHC reasonably well. WHC of Shoot ${ }_{\text {int }}$, by contrast, should perhaps be considered an entirely separate trait.

Because WHC of Shoot int+ext $_{\text {and colony were well-correlated (Fig. A2), differences }}$ between tundra bryophyte functional groups (BFGs) were analyzed for WHC of Shoot $_{\text {int+ext }}$ and colony together with a mixed effects model followed by Tukey's HSD test. To take into account potential structural biases across studies, study ID was included as a random factor. Species was nested inside study ID to take into account the expected smaller variation within compared with between bryophyte species. 
Table A1. Methods of individual water holding capacity (WHC) studies. Full references for published studies can be found in the reference list for the main text. Water

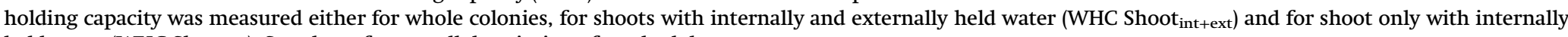
held water (WHC Shoot ${ }_{\text {int }}$ ). See above for overall description of methodology.

\begin{tabular}{|c|c|}
\hline Study & Description \\
\hline \multicolumn{2}{|l|}{ WHC colony } \\
\hline Elumeeva et al. 2011 & $\begin{array}{l}\text { Colonies kept in plastic containers. Shoots of non-target species removed to }<1 \% \text {. Colonies } \\
\text { remoistened and surplus water drainage allowed. Samples weighed and full moisture and } \\
\text { after oven-drying at } 90^{\circ} \mathrm{C} \text { until a constant mass. }\end{array}$ \\
\hline $\begin{array}{l}\text { Jónsdóttir, unpublished data, } \\
2020\end{array}$ & $\begin{array}{l}\text { Colonies kept in plastic containers. Shoots of non-target species removed to }<1 \% \text { (usually not } \\
\text { needed). Colonies sprayed with water until saturated and allowed to drain surplus water. } \\
\text { Weighed at full saturation and after drying at } 70^{\circ} \mathrm{C} \text {. }\end{array}$ \\
\hline Lett et al. 2017 & $\begin{array}{l}\text { Colonies kept in plastic containers. Shoots of non-target species removed to }<1 \% \text {. Colonies } \\
\text { sprayed with water until field saturation and allowed to drain surplus water. Weighed at full } \\
\text { water and after oven-drying at } 85^{\circ} \mathrm{C} \text { until a constant mass. }\end{array}$ \\
\hline
\end{tabular}

Liu and Rousk 2021

Colonies kept in plastic containers. Shoots of non-target species removed to $<1 \%$. Placed in a tray of distilled water for $12 \mathrm{~h}$ to saturate and allowed to drain surplus water. Weighed at full water and after oven-drying at $65^{\circ} \mathrm{C}$ until a constant mass.

May et al. 2018

Vertical faces of colonies wrapped in cellophane and placed in trays. Colonies had vascular plants and soil removed and contained $95 \%$ target species moss. Placed in a tray of distilled water $(3 \mathrm{~cm}$ depth) to hydrate. Soaked for $2 \mathrm{~h}$ until full saturation, then drained for $1 \mathrm{~h}$. Colonies weighed after draining and at $0 \%$ water content after dried at $50{ }^{\circ} \mathrm{C}$.

Michel et al. $2012 \quad$ Colonies kept in plastic containers. Shoots of non-target species removed to $<1 \%$. Colonies sprayed with water until field saturation and allowed to drain surplus water. Weighed at full water and after oven-drying at $60{ }^{\circ} \mathrm{C}$ until a constant mass.

Rzepczynska, Michelsen, and Lett, unpublished data 2019

Colonies kept in plastic containers. Non-target species removed ( 95\%). Sprayed with distilled water until full saturation, allowing the excess water to drain. Samples were weighed and then dried at $85^{\circ} \mathrm{C}$ for $48 \mathrm{~h}$.

Soil removed. Soaked in water for $30 \mathrm{~min}$. Suspended in sealed container with water at the bottom for $24 \mathrm{~h}$ at $22{ }^{\circ} \mathrm{C}$ to allow excess of water drops and prevent evaporation. Then, weighed, oven-dried for $72 \mathrm{~h}$ at $70^{\circ} \mathrm{C}$ and weighed again.

Rui, Vandvik, and Haugum, unpublished data, 2018

Elumeeva et al. 2011

Rzepczynska, Michelsen, and Lett, unpublished data, 2019

Separate shoots remoistened in deionized water for $\min 12 \mathrm{~h}$ before weighing at full turgor. Less than $30 \mathrm{~s}$ before initial weighing every shoot was taken out of the water, shaken and lightly blotted to remove the extra external water not well connected with the shoot structures. Shoots dried at $90^{\circ} \mathrm{C}$ until constant mass and weighed again.

Shoots collected from each sample placed in a glass vial and sprayed with distilled water until full turgor. Vials sealed with perforated parafilm for $24 \mathrm{~h}$, shoots then weighed before and after drying at $50{ }^{\circ} \mathrm{C}$ for $48 \mathrm{~h}$.
Dimensions

$\mathrm{N}: 5$, area: $7.5 \times 7.5 \mathrm{~cm}^{2}$, depth: similar height as in field, green and basal parts included

$\mathrm{N}$ : 10, area $19.6 \mathrm{~cm}^{2}$ (circle, $5 \mathrm{~cm}$ in diameter), trimmed to $5 \mathrm{~cm}$ depth

$N: 4$, area: $11 \times 11 \mathrm{~cm}^{2}$, depth: $2.8-7.3 \mathrm{~cm}$ depending on species, green and basal parts included

$\mathrm{N}: 3$, area: $10.75 \mathrm{~cm}^{2}$ (circle, $3.7 \mathrm{~cm}$ Ø), depth: $2.1-7.8 \mathrm{~cm}$ depending on species, green and basal parts included

$\mathrm{N}: 4$, area: $20 \times 20 \mathrm{~cm}^{2}$, depth: fixed depth, $8 \mathrm{~cm}$

$\mathrm{N}$ : 6 for each colony, 16 colonies area: $19.6 \mathrm{~cm}^{2}$ (circle $5 \mathrm{~cm}$ in diameter), depth: fixed depth, $5 \mathrm{~cm}$

$\mathrm{N}$ : 20; dimensions varied among species (volume 3 to $248 \mathrm{~cm}^{3}$ )

$N$ : 30, Sample size: $1 \mathrm{~g}$ dry weight

N: 10, Sample size: 1 shoot

$N$ : 20, number of shoots differed between species, always covering area of $1 \mathrm{~cm}^{2}$ 
Table A1. (concluded).

Study

Description

N: 10 , Sample size $: 1$ shoot,

Shoots submersed in demineralized water for $30 \mathrm{~min}$. Placed on moistened filter paper in sealed Petri dishes for $\sim 24 \mathrm{~h}$. Shoots blotted dry and weighed, air-dried and weighed again (i.e., the top part of the shoot For each batch of samples, one replicate was oven-dried at $40{ }^{\circ} \mathrm{C}$ for $6 \mathrm{~h}$ and weighed to with green leaves) provide a conversion factor between air-dry and oven-dry mass.

van Zuijlen et al. 2021

Elumeeva et al. 201

Michel et al. 2012
Same as Roos et al. 2019, except one replicate per batch was oven-
provide a conversion factor between air-dry and oven-dry mass).

provide a conversion factor between air-dry and oven-dry mass). Shoots moistened in deionized water and shaken to remove water against gravity, then blotted to remove as much external water as possible and weighed. Shoots oven-dried at $90^{\circ} \mathrm{C}$ Shoots moistened in deionized water and shaken to remove water, then blotted to remove as much external water as possible and weighed. Shoots oven-dried at $60^{\circ} \mathrm{C}$ for $48 \mathrm{~h}$.
Same as Roos et al. 2019

$N$ : 12, Sample size: 1 shoot.

N: 6 shoots for each species, 16 colonies, 8 species 
Fig. A1. The twelve bryophyte functional groups (BFGs) and their abbreviations illustrated with photos of characteristic species, a-1. (a), Sphagnum fuscum (Schimp.) H. Klinggr.; (b), Climacium dendroides (Hedw.) F. Weber \& D. Mohr; (c), Hylocomium splendens (Hedw.) Schimp.; (d), Hypnum cupressiforme Hedw.; (e), Tomentypnum nitens (Hedw.) Loeske; (f), Grimmia pulvinata (Hedw.) Sm.; (g), Racomitrium lanuginosum (Hedw.) Brid.; (h), Aulacomnium turgidum (Wahlenb.) Schwägr.; (i), Dicranum fuscescens (Brid.) Wilson; (j), Polytrichum commune Hedw.; (k), Ptilidium ciliare; and (1), Marchantia foliacea. White bars indicate approximate scale. Photos c, e, h by Signe Lett and a, b, d, f, g, i, j, k, 1 through Creative Commons (commons.wikimedia.org)((a) https://commons.wikimedia.org/wiki/File:Sphagnum_ fuscum_(b,_150951-474701)_4200.JPG; (b) https://commons.wikimedia.org/wiki/File:Climacium_dendroides_-Flickr_-_pellaea_(1).jpg; (d) https://commons.wikimedia.org/wiki/File:Hypnum.cupressiforme.jpg; (f) https:// commons.wikimedia.org/wiki/File:Grimmia_pulvinata_91974896.jpg; (g) https://commons.wikimedia.org/wiki/File: Iceland_Crack_4328.JPG; (i) https://commons.wikimedia.org/wiki/File:Dicranum_flexicaule_(a,_141118-472329)_ 5339.JPG; (j) https://commons.wikimedia.org/wiki/File:Polytrichum_commune_(g,_144843-474723)_0636.JPG; (k) https://commons.wikimedia.org/wiki/File:Ptilidium_ciliare_(a,_132028-465914)_6839.JPG; (1) https://commons. wikimedia.org/wiki/File:Brunnenlebermoos_Marchantia_polymorpha_Regen_nahe_Viechtach-001.jpg).
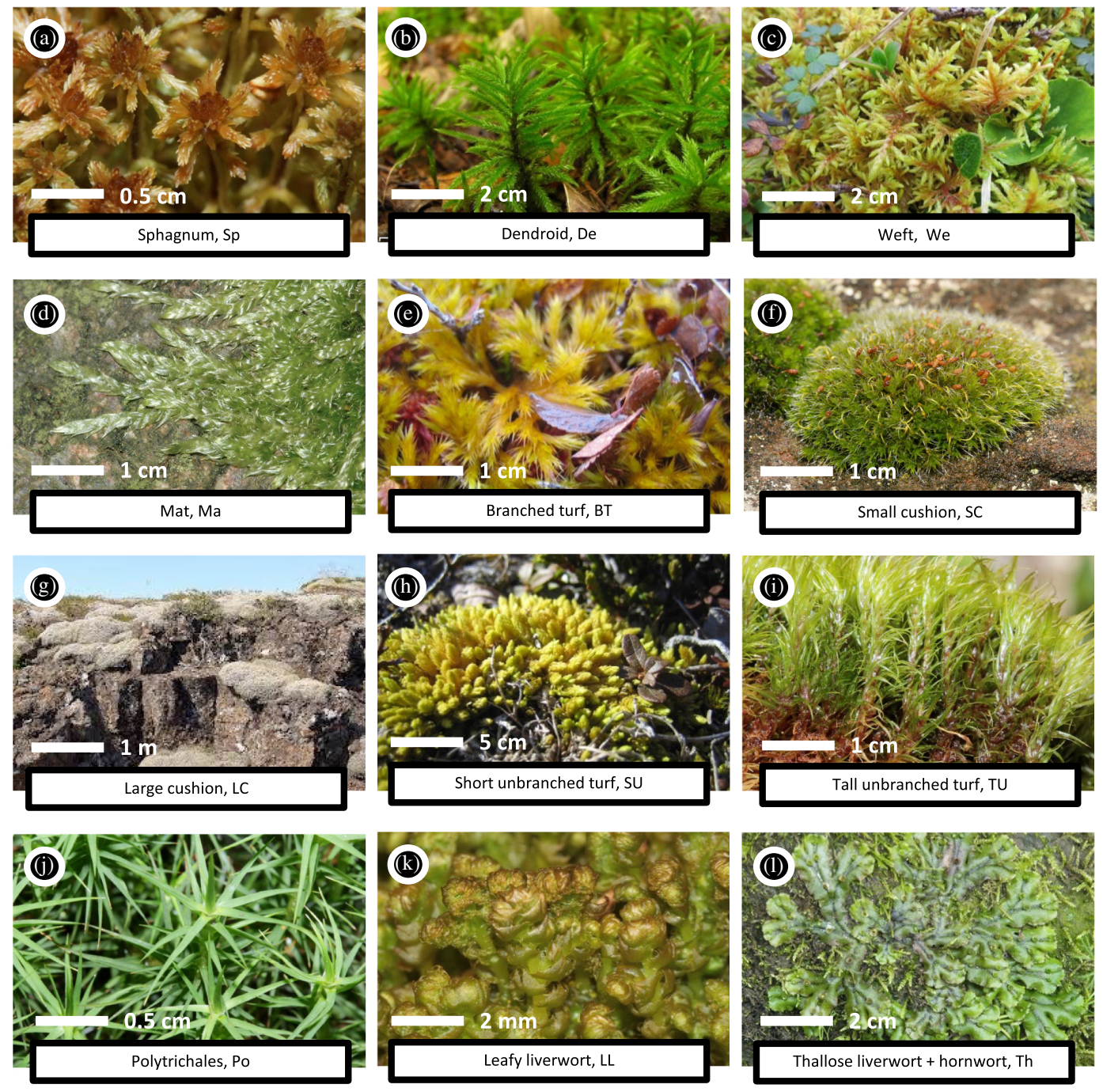
Fig. A2. Relationships between water holding capacity (WHC) in (a) bryophyte colonies, (b) shoots external and internal, and (c) in shoots only internal. Dots represent species means and are colored according to tundra bryophyte functional groups (TBFGs; We, Weft; Ma, Mat; BT, Branched turf; SU, Short unbranched turf; TU, Tall

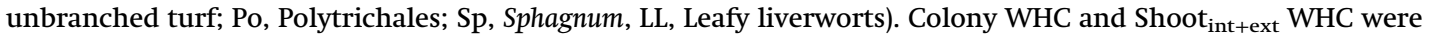
significantly correlated, whereas Shoot ${ }_{\text {int }}$ WHC did not correlate to colony or Shoot ${ }_{\text {ext }}$ WHC (b,c).

(a)

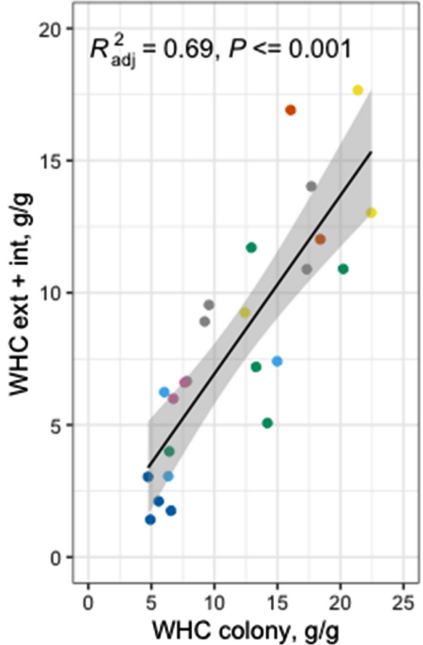

(b)

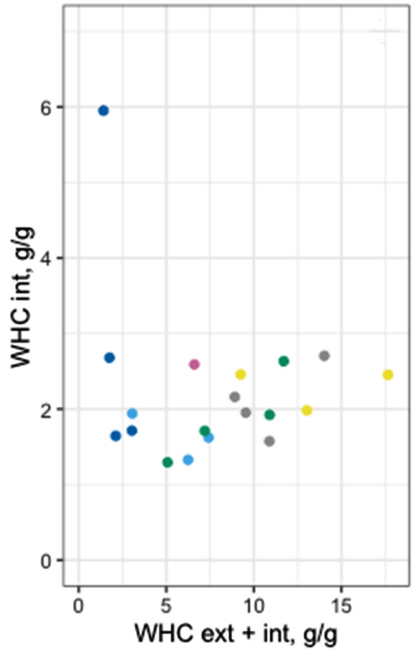

(c)

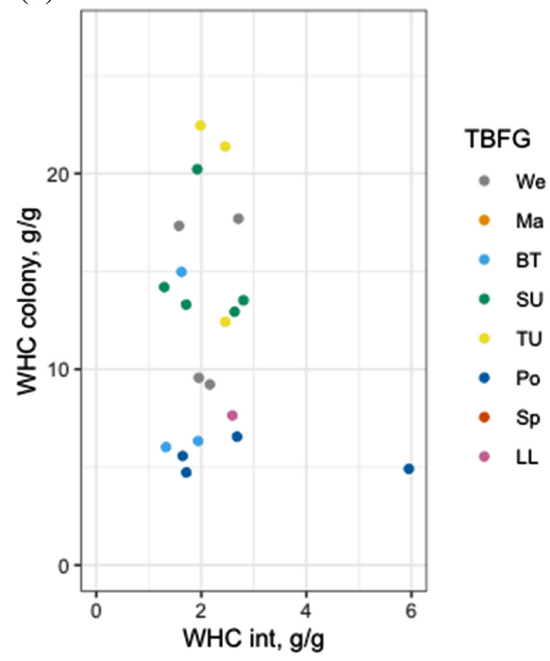


Fig. A3. Water holding capacity of bryophyte colonies (open circles) and shoot including external moisture (closed circles) measured in gram water per gram dry weight bryophyte. Bryophyte species are ordered according to tundra bryophyte functional groups (TBFGs; Po, Polytrichales; BT, Branched turf; LL, Leafy liverworts; We, Weft; SU, Short unbranched turf; TU, Tall unbranched turf; Ma, Mat; Sp, Sphagnum). Color of dots indicate study ID (Michel et al. 2012; Elumeeva et al. 2011; Lett et al. 2017; May et al. 2018; S.B. Rui, V. Vandvik, and S. Haugum, unpublished data, 2018; I.S. Jónsdóttir, unpublished data, 2020; Liu and Rousk 2021, A.M. Rzepczynska, A. Michelsen, and S. Lett, unpublished data, 2019). Boxes contain 1st and 3rd quartile and show median, dots outside whiskers indicate values more than 1.5 times the length of the box.

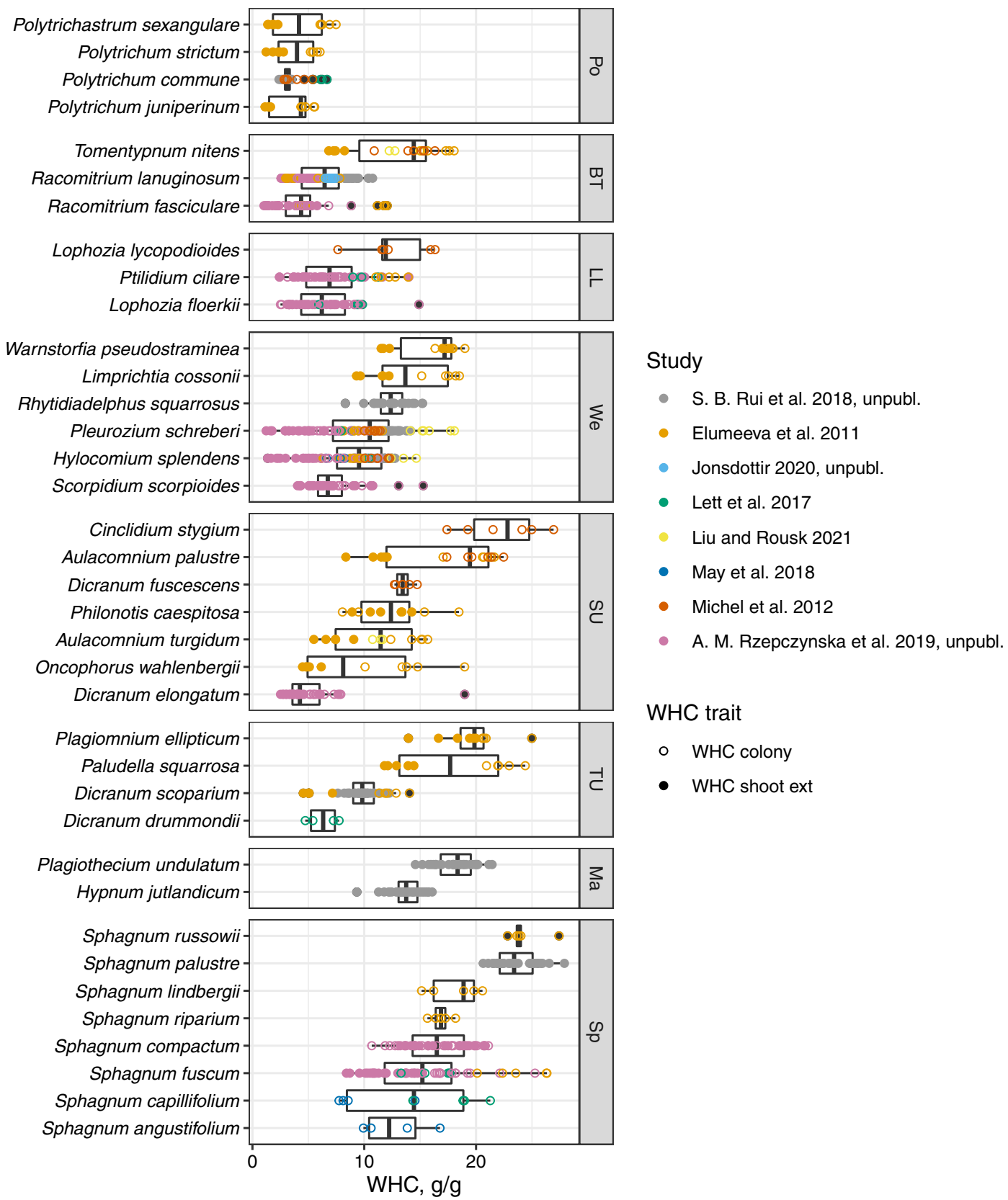

Published by Canadian Science Publishing 
Table A2. List of recommended bryophyte floras and species lists (*) covering Arctic areas. The list is not comprehensive. Where available, number of species is given.

\begin{tabular}{|c|c|c|c|c|c|}
\hline Arctic region & Flora/species list* & Language & Authors (ref) & Year & Comment \\
\hline \multicolumn{6}{|c|}{ North America } \\
\hline & Flora of North America, Vol. 27 and 28 & English & $\begin{array}{l}\text { Flora of North America } \\
\text { Committee }\end{array}$ & 2007, 2014 & $\begin{array}{l}\text { Mosses. Available as e-book, } \\
621+698 \text { species }\end{array}$ \\
\hline \multirow{2}{*}{ USA } & The mosses of Arctic Alaska* & English & W.C. Steere & 1978 & Mosses. 415 species Out of print \\
\hline & $\begin{array}{l}\text { A Bryophyte Species List for Denali National } \\
\text { Park and Preserve, Alaska, with } \\
\text { Comments on Several New and } \\
\text { Noteworthy Records* }\end{array}$ & English & $\begin{array}{l}\text { S.E. Stehn, J.K. Walton, } \\
\text { C.A. Roland }\end{array}$ & 2013 & $\begin{array}{l}\text { Bryophytes, Covers Denali } \\
\text { National Park, } 499 \text { species }\end{array}$ \\
\hline \multirow[t]{3}{*}{ Canada } & $\begin{array}{l}\text { Flore des bryophytes du Québec et du } \\
\text { Labrador, Vol. 1-3 }\end{array}$ & French & J. Faubert & 2012 & Bryophytes, 892 species \\
\hline & $\begin{array}{l}\text { A key and annotated synopsis of the mosses } \\
\text { of the northern lowlands of Devon } \\
\text { Island, N.W.T., Canada }\end{array}$ & English & V.D. Vitt & 1975 & $\begin{array}{l}\text { Mosses. Covers Devon Island. } 131 \\
\text { species }\end{array}$ \\
\hline & $\begin{array}{l}\text { The Mosses of Northern Ellesmere Island, } \\
\text { Arctic Canada. II. Annotated List of the } \\
\text { Taxa* }\end{array}$ & English & G.R. Brassard & 1971 & $\begin{array}{l}\text { Mosses. Covers North Ellesmere } \\
\text { Island. } 151 \text { species }\end{array}$ \\
\hline \multicolumn{6}{|l|}{ Greenland } \\
\hline & $\begin{array}{l}\text { Illustrated Moss Flora of Arctic North } \\
\text { America and Greenland vol. 1-3 }\end{array}$ & English & $\begin{array}{l}\text { D. Long, H. Crum, } \\
\text { B. Murray, } \\
\text { G. Mogensen, ed. }\end{array}$ & 1985 & $\begin{array}{l}\text { 1. Polytrichaceae, 2. Sphagnaceae, } \\
\text { 3. Andreaeobryaceae - } \\
\text { Tetraphidaceae. Out of print }\end{array}$ \\
\hline & Liverworts of Greenland & English & K. Damsholt & 2013 & Liverworts, 178 species \\
\hline & $\begin{array}{l}\text { Mosses (Bryophyta) and liverworts } \\
\text { (Marchantiophyta) of the Zackenberg } \\
\text { valley, northeast Greenland* }\end{array}$ & English & $\begin{array}{l}\text { K. Hassel, H. Zechmeister, } \\
\text { T. Prestø }\end{array}$ & 2014 & $\begin{array}{l}\text { Mosses and liverworts, } 212 \\
\text { species }\end{array}$ \\
\hline \multicolumn{6}{|l|}{ Fennoscandia } \\
\hline \multirow{5}{*}{ Iceland } & $\begin{array}{l}\text { Illustrated Moss Flora of Fennoscandia. II. } \\
\text { Musci. Vol. 1-6 }\end{array}$ & English & E. Nyholm & 1954-1969 & Bryophytes. Out of print \\
\hline & Illustrated flora of Nordic Mosses, Vol. 1-4 & English & E. Nyholm & 1987-1998 & Mosses; vol 4 out of print \\
\hline & $\begin{array}{l}\text { Illustrated moss flora of Nordic liverworts } \\
\text { and hornworts }\end{array}$ & English & K. Damsholt & 2009 & $\begin{array}{l}\text { Liverworts and hornworts. Out of } \\
\text { print }\end{array}$ \\
\hline & Íslenskir mosar & Icelandic & B. Jóhannsson & 1989-2003 & $\begin{array}{l}\text { Bryophytes. Available as reports. } \\
604 \text { species, detailed } \\
\text { descriptions and distribution } \\
\text { maps for Iceland }\end{array}$ \\
\hline & Mosar á Íslandi & Icelandic & Á. H. Bjarnsson & 2018 & $\begin{array}{l}\text { Bryophytes. Key to all species in } \\
\text { Iceland }\end{array}$ \\
\hline
\end{tabular}

English

osses. Covers Devon Island. 131

osses. Cove

Island. 151 specie 
Table A2. (concluded).

\begin{tabular}{|c|c|c|c|c|c|}
\hline Arctic region & Flora/species list* & Language & Authors (ref) & Year & Comment \\
\hline \multirow[t]{3}{*}{ Norway } & Norges torvmoser & Norwegian & K.I. Flatberg & 2014 & Sphagnaceae. 55 species \\
\hline & Bryophytes of the Longyearbyen area* & English & $\begin{array}{l}\text { T. Prestø, M. Lüth, } \\
\text { K. Hassel }\end{array}$ & 2014 & Bryophytes \\
\hline & $\begin{array}{l}\text { Bryophytes, lichens and cyanoprocaryotes } \\
\text { in surrounding of pyramiden (Svalbard): } \\
\text { A consise handbook }\end{array}$ & English & $\begin{array}{l}\text { M. Dodd, I. Tatarenko, } \\
\text { N. Koroleva }\end{array}$ & 2015 & $\begin{array}{l}\text { Bryophytes, subset of Svalbard } \\
\text { species, } 87 \text { species }\end{array}$ \\
\hline \multirow[t]{3}{*}{ Sweden } & National Nyckeln, 4 volumes & $\begin{array}{l}\text { Swedish }+ \\
\quad \text { English }\end{array}$ & $\begin{array}{l}\text { T. Hallingbäck, N. Lönnel, } \\
\text { H. Weibull, L. Hedenås }\end{array}$ & 2005-2019 & All mosses, 852 species \\
\hline & Mossor & Swedish & T. Hallingbäck & 2016 & All bryophytes \\
\hline & $\begin{array}{l}\text { Bryophytes of the Tornetraesk area, } \\
\text { northern Swedish Lapland* }\end{array}$ & English & O. Mårtensson & 1956 & Bryophytes \\
\hline \multicolumn{6}{|l|}{ Russia } \\
\hline & Moss Flora of Russia, Vol. 2, 4 and 5 & $\begin{array}{l}\text { Russian, } \\
\text { English }\end{array}$ & M.S. Ignatov et al. & $\begin{array}{l}2017,2018 \\
\quad 2020\end{array}$ & $\begin{array}{l}\text { Oedipodiales-Grimmiales; } \\
\text { Bartramiales-Aulacomniales; } \\
\text { Hypopterygiales - Hypnales } \\
\text { (Plagiotheciaceae - } \\
\text { Brachytheciaceae) }\end{array}$ \\
\hline \multicolumn{6}{|c|}{ Other useful resources } \\
\hline Britain and Ireland & $\begin{array}{l}\text { Mosses and Liverworts of Britain and } \\
\text { Ireland-a field guide }\end{array}$ & English & $\begin{array}{l}\text { I. Atherton, S. Bosanquet, } \\
\text { M. Lawley }\end{array}$ & 2010 & $\begin{array}{l}\text { Mosses, Liverworts and } \\
\text { Hornworts. }\end{array}$ \\
\hline
\end{tabular}




\section{Reference list for Table A2}

Atherton, I., Bosanquet, S.D.S., and Lawey, M. 2010. Mosses and liverworts of Britain and Ireland: a field guide. British Bryological Society.

Bjarnason, Á.H. 2018. Mosar á Íslandi. Forlagid.

Brassard, G.R. 1971. The Mosses of Northern Ellesmere Island, Arctic Canada. II. Annotated List of the Taxa. The Bryologist, 74(3): 282-311.

Committee F of NAE. (Editor). 2007. Flora of North America: Vol. 27: Bryophytes: Mosses, Part 1: North of Mexico. New York, NY: Oxford University Press. 734 p.

Crum, H.A. 1986. Illustrated moss flora of Arctic North America and Greenland. Mogensen GS, editor. Museum Tusculanum Press. (Monographs on Greenland; Vol. 2. Sphagnaceae).

Damsholt, K. 2009. Illustrated moss flora of Nordic liverworts and hornworts. Lund, Sweden: Oikos editorial office. Damsholt, K. 2013. Liverworts of Greenland. Lund, Sweden: Oikos editorial office.

Dodd, M., Tatarenko, I., and Koroleva, N. 2015. Bryophytes, lichens and cyanoprocaryotes in surroundings of Pyramiden (Svalbard): a concise guide-book. Dodd M, Tatarenko I, Koroleva N, editors. Apatity, Murmansk: Polar-Alpine Botanical Garden-Institute, 253 p.

Faubert, J. 2012. Flore des Bryophytes du Quebec-Labrador. Vols. 1-3. Société Québécoise de Bryologie.

Flatberg, K.I. 2014. Norges Torvmoser. Norway: Akademiska Forlag.

Hallingbäck T. 2016. Mossor: En fältguide. Naturcentrum.

Hallingbäck, T., Lönnell, N., and Weibull, H. 2008. Bladmossor : kompaktmossor - kapmossor. Bryophyta : anoectangium - orthodontium. Vol. AJ 24-36. SLU Artdatabanken.

Hallingbäck, T., Lönnell. N., Weibull, H., and Hedenäs, L. 2005. Bladmossor: Sköldmossor - blåmossor: Bryophyta: Buxbaumia - Leucobryum klot. SLU Artdatabanken, 416 p.

Hassel, K., Zechmeister, H., and Prestø, T. 2014. Mosses (Bryophyta) and liverworts (Marchantiophyta) of the Zackenberg valley, northeast Greenland. Lnbg. 37(2): 66-84.

Hedenäs, L., and Hallingbäck, T. 2014. Bladmossor : skirmossor - baronmossor. Bryophyta : hookeria - anomodon. Vol. AJ 37-57. SLU Artdatabanken.

Ignatov, M.S., Ignatova, E.A., and Fedosov, V.E. 2017. Moss Flora of Russia. Vol. 2. Oedipodiales-Grimmiales. Moscow, Russia: KMK.

Ignatov, M.S., Ignatova, E.A., and Fedosov, V.E. 2018. Moss Flora of Russia. Vol. 4. Bartramiales-Aulacomniales. Moscow, Russia: KMK.

Ignatov, M.S., Ignatova, E.A., and Fedosov ,V.E. 2020. Moss Flora of Russia. Vol. 5. Hypopterygiales-Hypnales (Plagiotheciaceae-Brachytheciaceae). Moscow, Russia: KMK.

Jóhansson, B. 2003. Íslenskir mosar (Icelandic bryophytes). Iceland: Fjörlrit Náttúrufræðistofnunar; 1989 Report No.: 12, 13, 15, 16, 19-22, 24, 26, 29, 30, 33, 36, 38 and 41-44.

Long, D.G. 1985. Illustrated Moss Flora of Arctic North America and Greenland. Mogensen GS, editor. Museum

Tusculanum Press, 64 p. (Monographs on Greenland; Vol. 1. Polytrichaceae).

Lönnell, N., and Hallingbäck, T. 2019. Bladmossor: Vitmossor - knappnålsmossor: Bryophyta: SphagnumTetrodontium. Vol. AJ 1-5. SLU Artdatabanken.

Mårtensson, O. 1955. Bryophytes of the Torneträsk Area, Northern Swedish Lappland I - Hepaticae. Kungl. Sv. Vetensk. Akad. avhandlingar i naturskyddsärenden 12.

Mårtensson, O.1956a. Bryophytes of the Torneträsk Area, Northern Swedish Lappland II - Musci. Kungl. Sv. Vetensk. Akad. avhandlingar i naturskyddsärenden 14.

Mårtensson, O. 1956b. Bryophytes of the Torneträsk Area, Northern Swedish Lappland III - General part. Sv. Vetensk. Akad. avhandlingar i naturskyddsärenden 15.

Murray, B.M. 1987. Illustrated Moss Flora of Arctic North America and Greenland. Edited by G.S. Mogensen GS. Museum Tusculanum Press. 40 p. (Monographs on Greenland; vol. 3. Andreaeobryaceae-Tetraphidaceae).

Nyholm, E. 1954. Illustrated Moss Flora of Fennoscandia. II. Musci. Vols. 1-6. Lund, Sweden: Swedish Natural Science Research Council.

Nyholm, E. 1987. Illustrated Flora of Nordic Mosses. Vol. 1. Fissedentaceae-Seligeriaceae. Lund, Sweden: Oikos editorial office.

Nyholm, E. 1990. Illustrated flora of Nordic Mosses. Vol. 2. Pottiaceae-Schistostegaceae. Lund, Sweden: Oikos editorial office.

Nyholm, E. 1993. Illustrated flora of Nordic Mosses. Vol. 3. Bryaceae-Plagiomniaceae. Lund, Sweden: Oikos editorial office.

Nyholm, E. 1998. Illustrated flora of Nordic Mosses. Vol. 4. Aulacomniaceae-Orthotrichaceae. Lund, Sweden: Oikos editorial office.

Prestø, T., Lüthm M., and Hassel, K. 2014. Bryophytes of the Longyearbyen area. Trondheim: NTNU Vitenskapsmuseet, Sektion for naturhistorie, p. 1-68. (NTNU Vitenskapsmuseet naturhistorisk notat).

Stehn, S.E., Walton, J.K., and Roland, C.A. 2013. A Bryophyte Species List for Denali National Park and Preserve, Alaska, with Comments on Several New and Noteworthy Records. Evansia. 30(1): 31-45.

Steere, W.C. 1978. The mosses of Arctic Alaska. Vaduz: J. Cramer.

Vitt, D.H. 1975. A key and annotated synopsis of the mosses of the northern lowlands of Devon Island, N.W.T., Canada. Canadian Journal of Botany, 53(19): 2158-2197. doi: 10.1139/b75-242. 